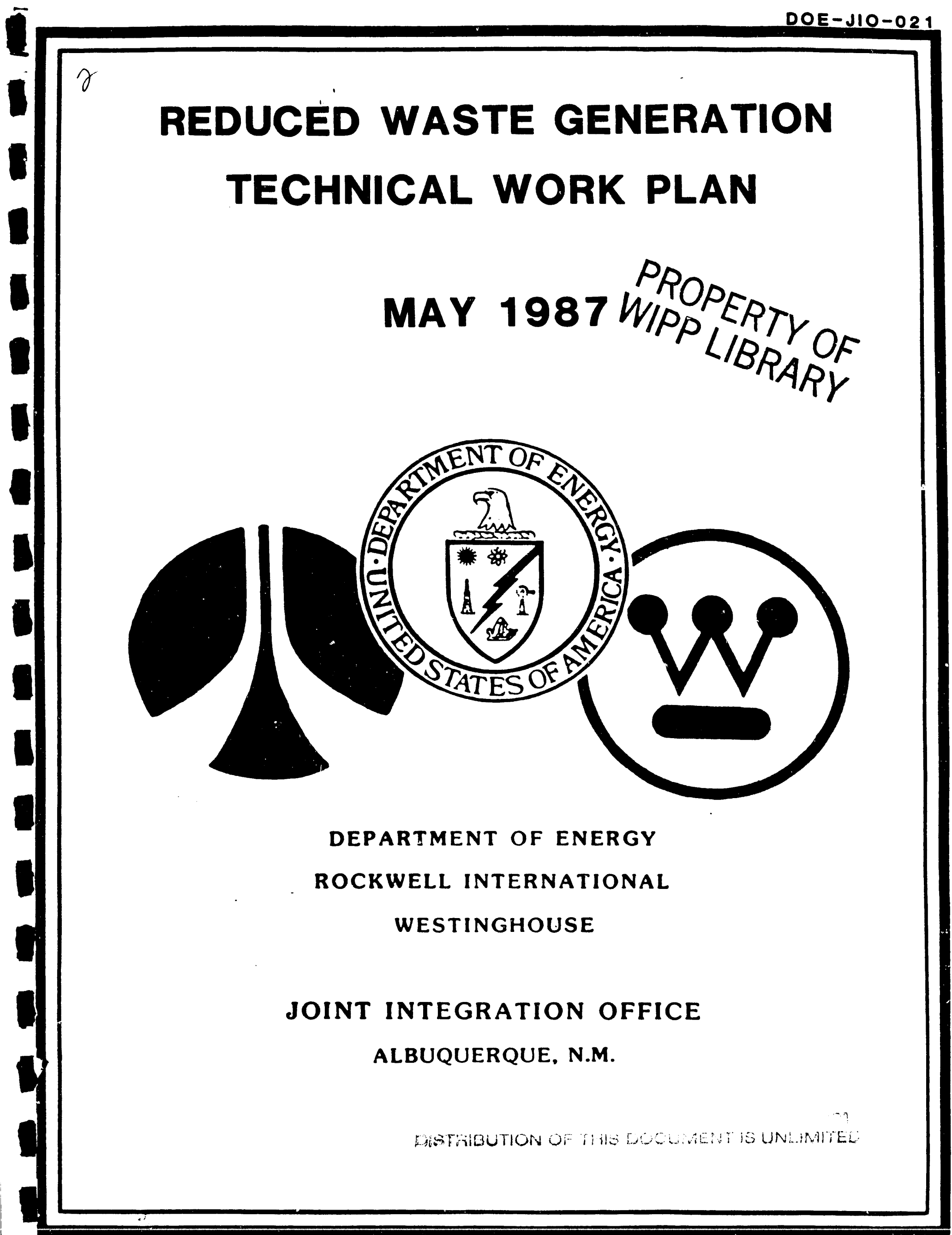


DOE/JIO- -021

DE92 000930

\section{REDUCED WASTE GENERATION \\ TECHNICAL WORK PLAN}

MAY 1987
Joint Integration office Albuquerque, NM

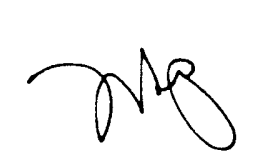

\section{MASTER}

DISTRIBUTION OF THIS DOCUMENT IS UNL!MITED 
1.0 Administrative Control 5

1.1 RWG - National Working Group 5

$\underline{2.0}$ Materials Research and Substitution 9

2.1 RWG - HEPA Filter Implementation 9

2.2 RWG - Equipment/Materials Replacement 14

3.0 Process Development or Optimization 19

3.1 RWG - TRUEX 19

3.2 RWG - PREPP Volume Reduction 24

$\begin{array}{ll}3.3 \text { RWG - Immobilization Improvement } & 28\end{array}$

4.0 Equipment Research and Development 32

4.1 RWG - Assay/Sort at Source 32

OVERALL COMPARATIVE SCORING OF FY87 TASKS

BACKGROUND INFORMATION AND RESULTS OF PREVIOUS YEARS' TASKS 40

$\begin{array}{ll}\text { SUMMARY OF COST/BENEFIT } & 49\end{array}$

DOCUMENTS PREPARED UNDER RWG TASKS

\section{DISCLA.IMER}

This report was prepared as an account of work sponsored by an agency of the United States Government. Neither the United States Government nor any agency thereof, nor any of their employees, makes any warranty, express or implied, or assumes any legal liability or responsibility for the accuracy, completeness, or usefulness of any information, apparatus, product, or process disclosed, or represents that its use would not infringe privately owned rights. Reference herein to any specific commercial product, process, or service by trade name, trademark, manufacturer, or otherwise does not necessarily constitute or imply its endorsement, recommendation, or favoring by the United States Government or any agency thereof. The views and opinions of authors expressed herein do not necessarily state or reflect those of the United States Government or any agency thereof. 
The United States Department of Energy has established policies for avoiding plutonium losses to the waste streams and minimizing the generation of wastes produced at its nuclear facilities. This policy is evidenced in DOE Order 5820.2, which states "Technical and administrative controls shall be directed towards reducing the gross volume of TRU waste genfrated and the amount of radioactivity in such waste." To comply with the DOE directive, the Defense Transuranic Waste Program (DTWP) supports and provides funding for specific research and development tasks at the various DOE sites to reduce the generation of waste.

This document has been prepared to give an overview of current and past Reduced waste Generation task activities which are to be based on technical and cost/benefit factors. The document is updated annually, or as needed, to reflect the status of program direction.

Reduced Waste Generation (RWG) tasks encompass a wide range of goals which are basically oriented toward 1) avoiding the generation of waste, 2) changing processes or operations to reduce waste, 3) converting TRU waste into LLW by sorting or decontamination, and 4 ) reducing volumes through operations such as incineration or compaction.

\section{TASK CATEGORIZATION}

The tasks contained within these goals can generally be categorized into four areas as follows:

Administrative Control:

The concept is to provide an impetus for waste reduction through activities such as 1 ) technology transfer; e.g. publications, seminars, and meetings; 2) awareness training programs; and 3) materials control; e.g. flow sheet reviews.

Materials Research and Substitution:

The tasks are for analyses of equipment, tools, enclosure surfaces, and other items that can be treated, designed, coated, or substituted for by other materials to extend useful life times.

Process Development or Optimization:

The tasks are to provide for the improvement or development of processes where a reduction in waste can be realized--i.e. replacement of complex, multi-step operations--or where secondary wastes could be reduced. 
Equipment Research and Development:

The tasks are for the utilization of new equipment or demonstration of existing equipment in a new way to effect waste reduction.

\section{TASK SELECTION CRITERIA}

The selection of tasks for prioritization and possible funding is based primarily on four factors: Cost/Benefit, Level of Development, Resource Availability, and Concurence of Management and DOE.

\section{Cost/Benefit:}

The cost of research and development, implementation, and operation must be weighed against the potential benefits. Cost factors for research and development are items such as labor, materials, equipment, overhead, and perhaps pilot plant operations. Cost factors for implementation would include items such as construction of facilities and equipment, and for operation would include cost of processing, packaging, certifying, storage, shipping, and disposal.

Benefits are primarily considered in terms of 1) volumes of waste avoided, converted into $L L W$, or reduced through changes in processing or operations; 2) transuranics not lost to waste streams; and 3) the added safety and reduction in radiation exposure from not handing the wastes.

Level of Technical Development:

The level of development reflects the risk factors for implementation and success. For example, tasks with little background and requiring long term research and development are normally considered a higher risk for eventual implementation. Generally the categories can be thought of as being in the following stages of development:

Theoretical, Bench, Pilot, or Pre-Implementation.

\section{Resource Availability:}

The selection of a task reflects directly on the resources of the applicant organization. For example, does the organization have available manpower, equipment, work area/gloveboxes, and support services such as Health Physics, Criticality Contol, Maintenance, and Utilities.

Concurrence of Management and DOE:

History indicates that changes in procedures or processes for the sake of improvement, understandably, are not always received favorably because of the status quo and risk factor. But research and development must have an end product; therefore, merit for task selection must be given to organizations with involvement and concurrence of the management and operations and the DOE field/area office. 
In concert with the concurrence of management and DOE, there must also be a logical plan for task completion. Therefore, within the discipline there must be a systematic approach for research and development and implementation activities. Consequently, tasks must follow certain plans for completion, depending, of course, on time and funding requirements.

\section{TASK SCORING AND EVALUATION}

The scoring and evaluation for task prioritization is based on weighting factors for each of the described categories: Level of Development, Resource Requirements, Management Involvement and Cost Benefit Analysis.

The evaluation method consists of scoring each task according to specific factors within each category. Both the individual factors and the categories are weighted by importance. The score for each factor within a category is normalized and then multiplied by its respective weight, giving a weighted factor score. The factor scores for the category are then summed together, giving a category score. Next the category score is multiplied by its respective weight, giving a weighted category score. The weighted category scores are then added giving a total task score.

For example, the category "Level of Technical Development" has only one factor, "Status of Developement" and a category weight of 0.15 .

There are four levels to Status of Developement: 1) Theoretical, 2) Bench, 3) Pilot, and 4) Pre-implementation, and each category is weighted in steps of $25 \%$.
1) Theoretical
0.25
2) Bench
0.50
3) Pilot
0.75
4) Pre-implementation 1.00

Therefore, if a task is at the "Pilot" stage of development, the score is 0.75 or $75 \%$. Since there is only one factor, the factor weight is 1 and the category total is $75 \%$. The category weighted score is then $75 \%$ times the weight of 0.15 or 0.112 .

The other categories, Cost/Benefit, Resource, and Management, are then treated in the same mannner, summed and totaled. 
In preparing this work plan the following subjects have been addressed for each of the current tasks:

Objective

\section{Background}

\section{Category Scoring}

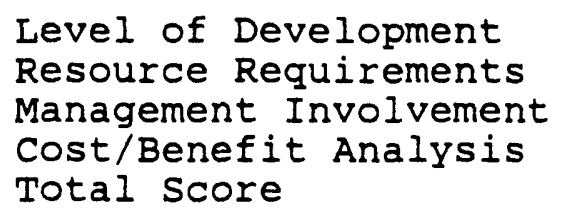

Work Planned

Guidance

Quality Level

Schedules/Milestones

Budget 


\subsection{ADMINISTRATIVE CONTROL}

$\begin{array}{ll}1.1 \quad \text { RWG - NATIONAL WORKING GROUP } & \text { AL/RFP } \\ \text { Program Manager } & \text { K. MCKinley, 474-3401 } \\ \text { Principal Investigator } & \text { P. Hagan, 474-3401 }\end{array}$

\section{Objective}

This task will be for the continuation of the National Working Group for Reduction in TRU Waste Arisings (NWGRTWA). Organizational objectives are to 1) exchange ideas on ways in which waste arisings can be minimized, 2) provide analytical input for task development and implementation, and 3 ) establish cooperative work efforts for technical development. Elements to accomplish these objectives will be to provide site and DOE program interfaces and to hold at least two major meetings. A summary Report will be prepared at the end of the fiscal year describing activities and accomplishments.

\section{Background}

The Working Group was organized in FY84, and the subsequent meetings that have been held are as follows:

1. The NWGRTWA held its first meeting in Northglenn, Co, October 14, 1983. organizational objectives were outlined and future tasks were defined.

2. The second meeting was held at LANL, February 23, 1984, and the principal subjects of discussion were 1) clarification of operational definitions, 2) investigation of bagless posting systems, 3) review of *roposed DTWP-RWA FY 1985 Tasks, and 4) investigation of glovebox HEPA filters.

3. The third meeting was held at the Hanford House in Richland, washington, July 19, 1984. The theme of this meeting was Reduction in Waste Through Equipment Selection and Preventative Maintenance. In addition, presentations were made on proposed waste reduction design features for the new Special Isotope separation (SIS) facility, the status of the bagless posting systems being installed at SRP and LANL, a systems study for remote handled waste, size reduction using high pressure water cutting and the RHO/LANL arc saw, and an update of the FY85-86 proposed tasks for Reduced Waste Generation. 
4. The fourth meeting was a US/UK Workshop on Reduction in Waste Arisings which was held at ORNL, May 13-15, 1985. The objective of this meeting, which was held under the US/UK bilateral agreement for waste management, was to exchange ideas on ways in which waste generation can be minimized though administrative control, materials substitution, equipment utilization, and process optimization.

5. The first FY86 National Working Group meeting for Waste Reduction was held October 23-24, 1985, at INEL. Discussions focused on reduction in waste through 1) optimizing waste immobilization, 2) disposal of spent resins, 3) assay instrumentation for waste sorting at the source of generation, 4) reduction in pyrochemical waste salts through recycle, 5) laser cutting technologies, 6) PREPP volume reduction, and 7) super compactors.

6. The second FY86 National Working Group for Waste Reduction meeting hosted a USDOE/FRG-BMFT Workshop on Waste Minimization and Processing at SRP, MaY 6-8, 1986. The purpose of the workshop was to exchange specific technical information on methodologies for waste minimization through sorting, processing, immobilizing, and packaging. Other issues addressed were safety and gas generation. A document was prepared entitled

"Proceedings of the U.S. DOE/FRG-BMFT Workshop on Waste Minimization and Processing."

\section{Category scoring}

Level of Development:

The NWGRTWA is well established and is functioning as planned. The category score is then 1.0 or $100 \%$. The category weighted score is then $100 \%$ times the category weight of 0.15 or 0.15 .

Resource Requirements:

Resource requirements are identified and in agreement with task needs.

1. Manpower: $0.5 \mathrm{MY}, 100 \%$ available

2. Equipment: None

3. Work Area/Gloveboxes: N/A

4. Facilities: N/A

All resources for the National Working Group are available. Hence the score for this category is $100 \%$ of the category weight or $\underline{0.15}$.

Management Involvement:

Management supports this task and the plan for carrying out objectives is complete. Hence the score for the management category is also $100 \%$ of the category weight or 0.15 . 
The value of the National working Group is that it provides a forum for the exchange of ideas and analytical input to the selection of tasks for further development. Although no data could be entered into the electronic worksheet due to the nature of the task, the National working Group is rated at $100 \%$ for Cost/Benefits. Thus the category score is 1008 times the category weight of 0.55 or $\underline{0.55}$.

Total Score:

As shown in Figure 1 , the category scores reflect the individual fractions of a maximum score of 1.0 (e.g. C/B e 0.55 + Technical e $0.15+$ Resources e $0.15+$ Management e $0.15=1.0$ ). For the NWGRTWA, full support was given, and the respective summaries are $0.55+0.15+0.15+0.15=1.00$.

Figure 1.

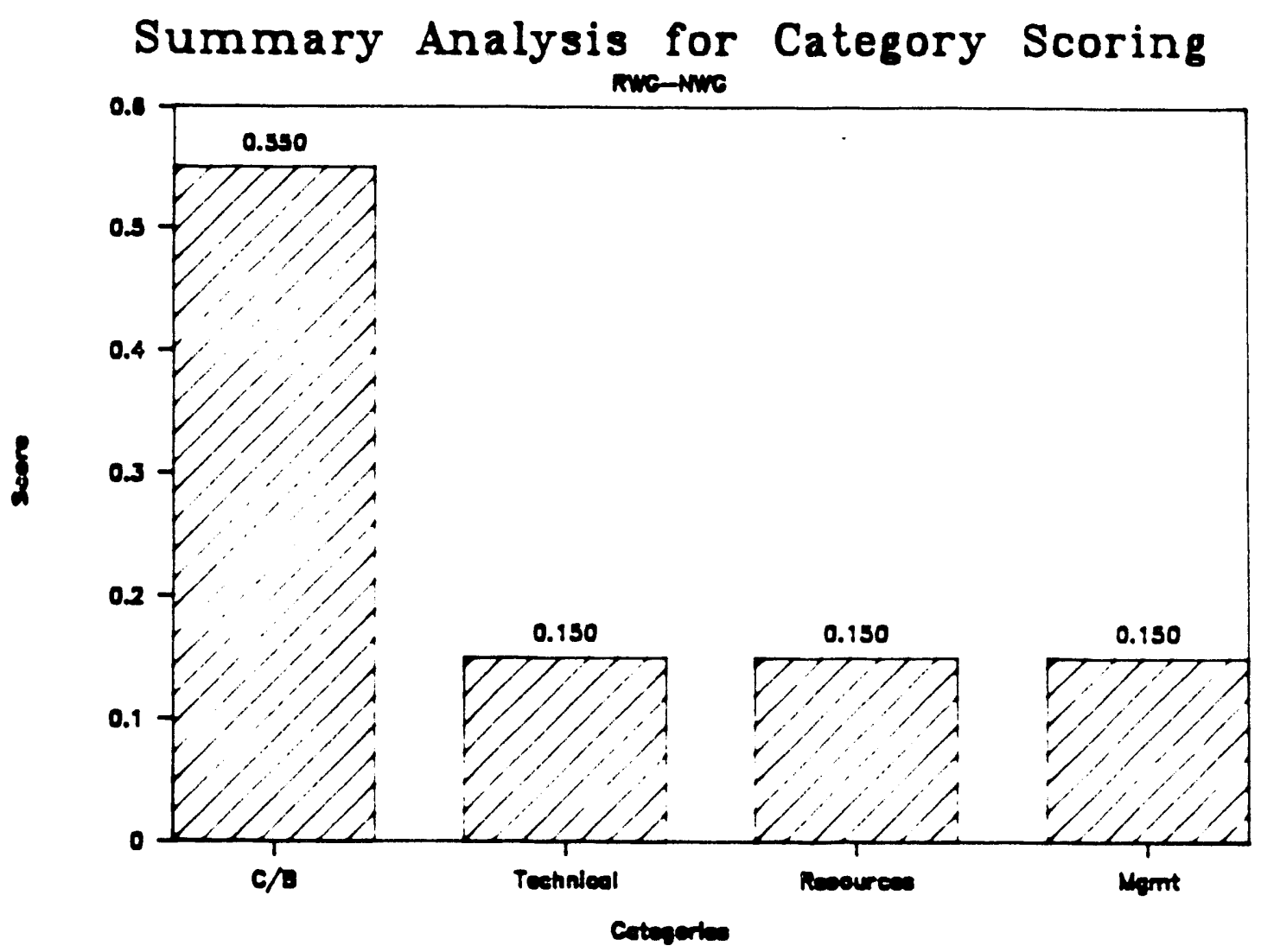




\section{Work Planned for FY87:}

Guidance :

Host two meetings at different sites and exchange information relevant to waste reduction, and submit a topical report entitled "FY 1987 Summary Report--National Working Group for Reduction in TRU Waste Arisings."

The first FY87 meeting of the National Working Group for Reduction in Transuranic waste Arisings was held concurrently with the "TRU Waste Update Meeting Number 13" at the Sheraton Triad Hotel and Towers, Salt Lake City, Utah, December 9-10, 1986. Objectives of the meeting were to 1) review current and proposed outyear tasks, 2) familiarize the NWGRTWA to the sensitivities associated with gathering and disseminating Reduced Waste Generation information, and 3) discuss methodologies for task selection, criteria for development, and completion.

Quality Level:

"C"

Schedule/Milestones:

FY87

A.

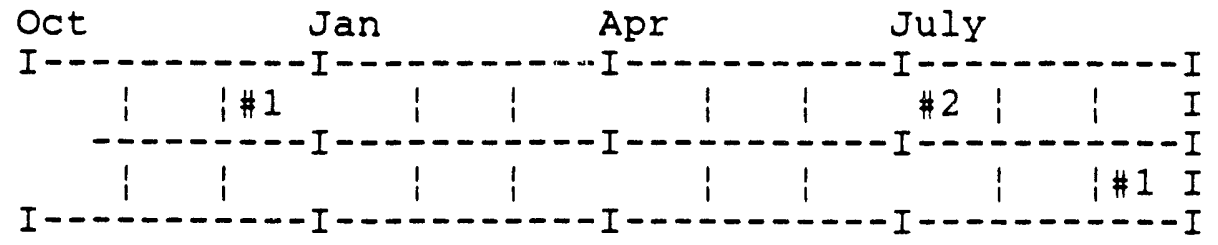

A. \#1 Host first FY87 NWGRWA workshop

\#2 Host second FY87 NWGRWA workshop

B. \#1 Complete report "FY 1987 Summary Report--National Working Group for Reduction in TRU Waste Arisings"

Budget :

Funding is $\$ 90 \mathrm{~K}$ in FY87. 


\subsection{Materials Research and Substitution}

\subsection{RWG - HEPA FILTER IMPLEMENTATION AL/RFP \\ Program Manager \\ Principal Engineer \\ J. Blakeslee, $320-4642$ \\ J. Ninni, 320-4830}

\section{Objective}

The task will be for the implementation of previous years' work on concepts for HEPA filter optimization and improvement and for the technology transfer of such work. Past work focused on studying 1) the administrative control of air filters used in production facilities to insure optimal usage and disposal, and 2) the potential for changes in air filtration techniques or materials that would improve the efficiency or longevity of the filters.

\section{Background}

Fiscal year 85 studies identified 1) the air filtration systems where most of the TRU filter waste originates and 2) the types of HEPA filters being employed within these systems. Gloveboxes were also identified as a place where prefilters could be used to extend the lifetime of the filters within the main air filtration systems.

As a result of this work:

1. An administrative change segregating stage HEPA filters from secondary filters was implemented. This change diverted 69 crates to the LLW category, resulting in an estimated cost savings of $\$ 342,000$ per year.

2. An analysis of the way Low Level and TRU filters are processed indicated that a 60 percent reduction in LLW volume could be achieved by crushing the filters.

3. Prefilter selection was investigated and a recommendation to use a low pressure drop "furnace" filter was made to extend the service life of the first stage of HEPA filters.

In FY86 prefilters were installed in HEPA filter plenums at the Rocky Flats Plant to determine if prefiltration systems would extend the life of first stage HEPA filters. Conclusions reached were that prefilters do extend the lifetime of HEPA filters and should be installed. When prefilters are fully implemented at RFP, the HEPA filters should last up to three times longer resulting in a volume reduction of 40 cubic meters per year, which at $\$ 3,500$ per cubic meter equals a cost saving of $\$ 140,000$. In additional work, a prefilter remote handing system was designed which will allow the prefilters to be removed from the plenum system without physical entry into the plenums. 
In another associated task. the characterization of spent HEPA filters, a study was conducted to determine if filters removed from service needed additional processing in order to meet the disposal ciriteria of the WIPP facility. The results from this work show that the spent HEPA filters do not contain dispersible particulates in excess of the criteria, and therefore the filters can be certified without immobilization processing. RFP currently generates about 198 cubic meters of filter waste per year, and by avoiding processing it is estimated that $\$ 7,900$ could be saved per cubic meter or about $\$ 1.5$ million per year.

\section{Category scoring}

Level of Technical development:

The R\&D and preliminary implementation will be completed this fiscal year, and it is anticipated that operations will continue with the implementation of prefilters as applicable to cost/benefic factors.

The weighting factor for "Level of Development" is 0.15 of a task toral of 1. Status of development ranges from 1) Theoretical, 2) Bench, 3) Pilot, and 4) Pre-implementation, with each category equal to $25 \%$, in steps, of the 0.15 weighting factor.

Therefore since this task is considered in the "Implementation" phase, the category score is 1.00 or $100 \%$. The category weighted score is $100 \%$ times the category weight of 0.15 or 0.15 .

Resource Requirements:

Resource requirements are identified and consistent with task needs.

1. Manpower: $1.0 \mathrm{MY}$; $100 \%$ available

2. Work Area/Gloveboxes: Work will be performed within the 700 Complex; therefore $100 \%$ available

3. Equipment: 1008 available

4. Su nort Services: $100 \%$ available

The category weight for "Resource Requirements" is 0.15 of a task total of 1. Resource Requirements range from 1) Manpower (which is equal to $40 \%$ of the 0.15 weight factor), 2) Work Area/Gloveboxes (20\%), 3) Equipment (20\%) and 4) Support services $(20 \%)$.

This task is considered to have the resources for completion; therefore, the category score is 1008 . The category weighted score is $100 \%$ times the category weight of 0.15 or 0.15 . 
Management Involvement:

Management supports this task and objectives are being carried out to completion.

The weighting factor for "Management Involvement" is 0.15 of a task total of 1 . Management Involvement ranges from 1) involvement and concurrence of all management systems, i.e. operations and DOE; and 2) logical plan for task completion. Each of these items carry 508 of the 0.15 weight factor.

This task is considered to have all management support and a logical plan; therefore, the category score is $100 \%$. The category weighted score is $100 \%$ times the category weight of 0.15 or $\underline{0.15}$.

\section{Cost/Benefit Analysis:}

FY86 estimates show a volume reduction of 18.8 cubic meters/year on a selected and less contaminated plenum (321). When fully implemented, the volume reduction is estimated to be 40 cubic meters per year, and at a $\$ 3500$ per cubic meter disposal cost the total is $\$ 140,000$ per year.

Weight: 0.55

Task Cost:

Research and Development $\$ 380,000$

Pilot Plant

Implementation

$\$ 125,000$

Facilities

Total Task Cost

$\$ 505,000$

Operational Costs:

\section{Labor}

Matarials

Packaging

Certifying

Storage

Shipping

Disposal

Sub Total Operational Costs

$\$ 3,500$ 
Potential reduction in volume in $\mathrm{M}^{3} /$ year

Operational cost savings times the volume of waste reduced

$\$ 140,000$

Estimated payback time in years

3.61 years

Other factors such as TRU saved, safety and reduction in radiation: Not included

The payback time was found by dividing the total task cost by the operational cost savings. The category score was arrived at by the analysis that a one year payback time is $100 \%$, 5 years being 0\%, on a straight line basis; e.g. 1 - [Payback Time - $1 /(5-1)]=$ o $x .55$. Therefore the 3.61 years equals a category score of 0.192 .

Total Score:

As shown in Figure 2, the category scores reflect the individual fractions of a maximum score of 1.0 (e.g. C/B 0.55 + Technical e $0.15+$ Resources e $0.15+$ Management e $0.15=1.0$ ). For this task, the respectives summaries were given: $0.192+0.15+0.15+$ $0.15=0.642$

Figure 2 .

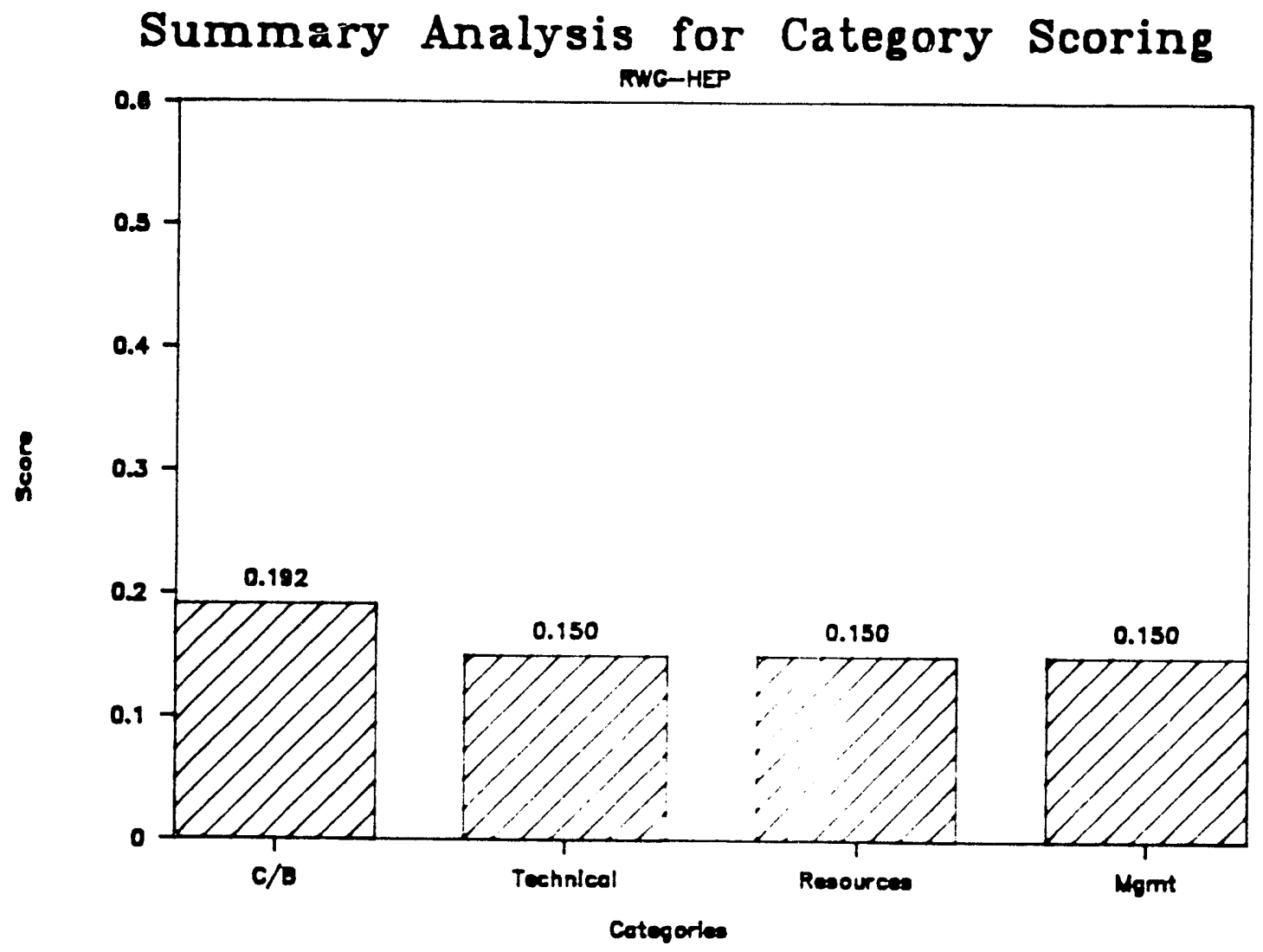




\section{Work Planned for FY87:}

Guidance :

Elements for completing the HEPA optimization/implementation work this fiscal year will be to 1) develop a work plan to implement prefilters for size 5 HEPA filters into plenums, 10/86, 2) install and test prefilters in selected plenums, $8 / 87,3$ ) complete design criteria for prefiltration systems which will include functions such as plenum service and air flow conditions, $6 / 87,4)$ install prefiltration systems with plant funds as available, 9/87, and 5) issue a final report that will include the design and recommendations for prefilter emplacement, projected waste volumes impacied by overall HEPA filter improvement management, anticipated cost/benefit analysis, and general improvement anticipated in filter waste management, 9/87.

Quality Level: "C"

Schedule/Milestones:

A.

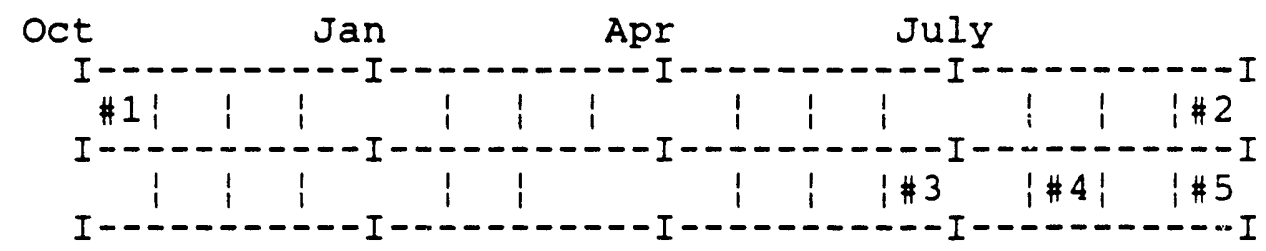

A. Reporting Functions

1) Develop a work plan to implement prefilters for size 5 HEPA

2) filters into plenums, $10 / 86$

B. Work Functions:

3) Complete design criteria for prefiltration systems which will include functions such as plenum service and air flow conditions, $6 / 87$

4) Install and test prefilters in selected plenums, 8/87

5) Install prefiltration systems with plant funds as available, $9 / 87$

Budget :

Funding requirements for FY87 are $\$ 130 \mathrm{~K}$.

This budget will be integrated into the overall RWG tasks for RFP targeted at $\$ 390 \mathrm{~K}$. Monthly expenditures, however, will be broken out for each of the tasks as they occur. 


\subsection{RWG - EQUIPMENT/MATERIALS REPLACEMENT \\ AL/RFP \\ Program Manager: \\ Principal Investigators: \\ J. Blakeslee, 320-4642 \\ F. Hobbs, 320-2134 \\ A. Phillips, 320-4346}

\section{Objective}

The task is for the analysis of equipment, tools, and other items that can be treated, designed, coated, or substituted for by other materials to extend useful life times. Previous work focused on 1) providing analysis and making recommendations for use of selected equipment that would last longer in harsh environments, 2) reviewing waste categories to determine specific waste forms that could be eliminated, and 3 ) providing rare earth coatings to crucibles and molds within the plutonium foundry areas to effect longer lifetime usage and waste reduction.

\section{Background:}

In FY84 work focused on reducing waste resulting from failed equipment in production operations. A research project was carried out to identify and test process equipment that would withstand the conditions in harsh environments. As a result of this effort, gear pumps, centrifugal canned motor pumps, and air operated valves were identified and tested, and were recommended for future use.

During FY85 the metal waste categories were reviewed to determine if specific areas of waste could be identified that are contributing to the overall waste generation. The results of this investigation show three major waste streams that make up the metal category at RFP. The first is the metal from strip out activities; the second from equipment discard; and the third from drum disposal. Continued efforts investigating the third category of waste revealed that by changing the sandling practices a large quantity of the drums, currently being crushed with the waste, could be recycled. A test was devised to demonstrate that new equipment could be used to dump waste from 55-gallon drums without contaminating the drum itself. The practice at RFP has been to package waste in drums and ship them to the size reduction area for re-packaging, and during the repackaging step the shipping drum became part of the TRU waste stream.

Consequently a procedural change for handling the drums at the size Reduction Vault in Building 776 was developed and tested. The change in the procedure is estimated to result in a reduction of 158 cubic meters per year, which at disposal cost of $\$ 3500 /$ cubic meter equals a cost sáving of $\$ 553,000$ per year.

The work in FY86 at RFP focused on developing rare earth coatings for crucibles and other plutonium foundry hardware. Results of this work culminated in the development of a new composite coating system which is comprised of an external layer of erbium oxide over layers of chromium, calcium fluoride, and an internal layer of erbium oxide bonded to an 
oxidation-resistant steel alloy. When implenented into production operations, equipment lifetimes will be extended by a factor of 150 and the anticipated cost savings through reducing the number of tantalum crucibles required and disposing of graphite molds is in the range of $\$ 2$ million per year.

\section{Category scoring}

Level of Development:

The level of development is pre-implementation. Therefore, the category score is 1.00 or $100 \%$. The category weighted score is 1008 times the Category weight of 0.15 or 0.15 .

Resource Requirements:

Resources are available. An impregnation machine is being purchased out of operations funding.

1. Manpower: $1.0 \mathrm{MY}$

2. Equipment: impregnation machine is necessary, and is being purchased.

3. Work Area/Gloveboxes: Bldg. $776 / 779$

4. Facilities: existing

The score for this category is therefore $100 \% \times 0.15=\underline{0.15}$

Management Involvement:

Acceptance of management/operations and DOE? Yes, therefore $100 \%$

Logical plan for task completion? Not totally definitive, therefore $50 \%$ is the weighted factor.

The score for this category is therefore:

$100+50$ divided by $2 \times 0.15=\underline{0.113}$

Cost/Benefit Analysis:

In FY87 a volume reduction in TRU waste from the procedural change in drum handling is anticipated to reduce waste volumes by 158 cubic meters per year. At an operational cost of $\$ 3500$ per cubic meter, the savings is equal to $\$ 553,000$ per year. The savings from utilizing permanant molds is estimated to be $\$ 2$ million per year. Equipment costs are estimated to be in the range of $\$ 8,000$ for FY87 and R\&D cost will be in the range of $\$ 122,000$ for FY87. 


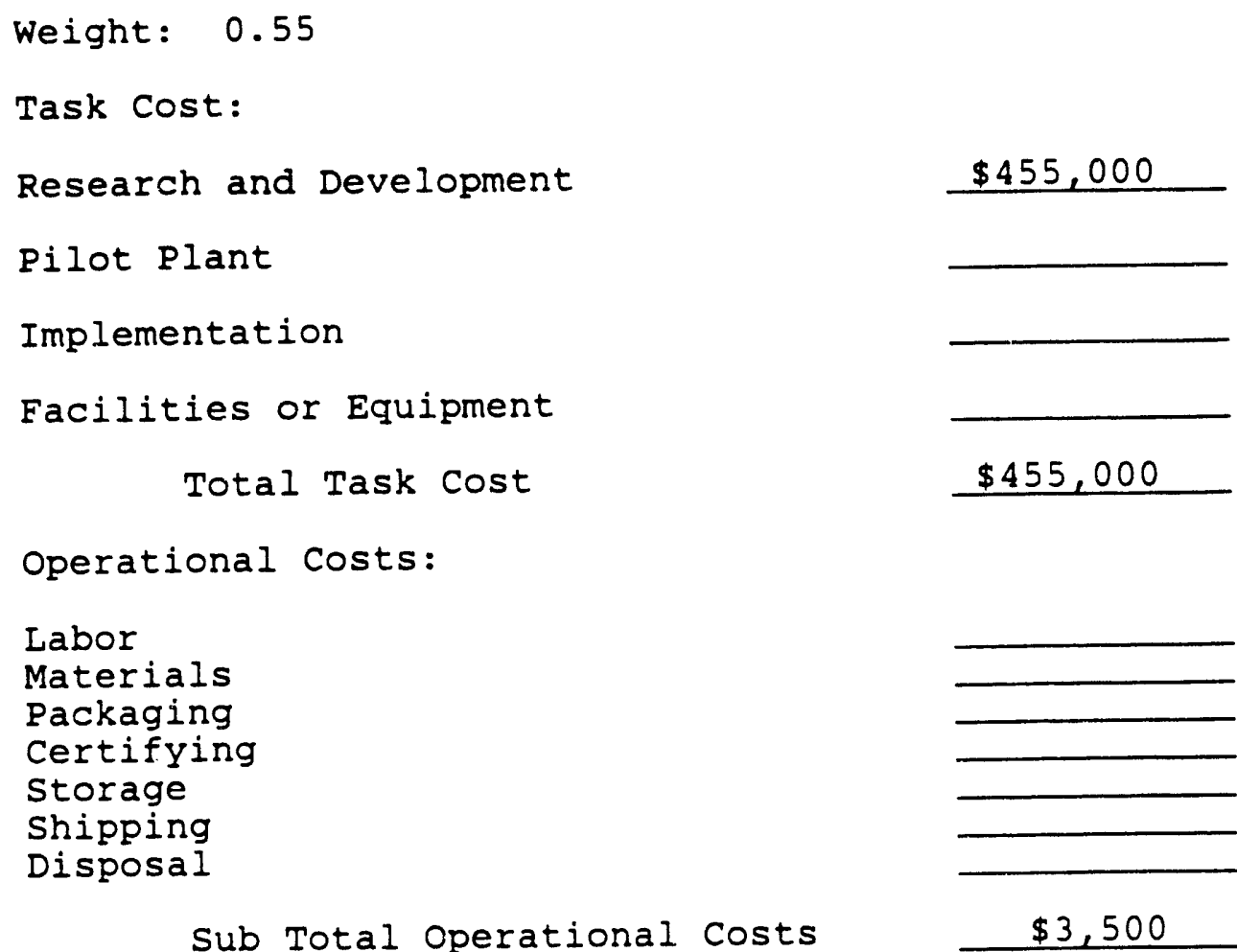

Sub Total Operational Costs

$\$ 3,500$

Potential reduction in volume in $\mathrm{M}^{3}$ /year Operational cost savings times the volume of waste reduced

$\frac{158}{\$ 553,000} \frac{\$ 2,000,000}{0.18 \text { years }}$

other cost savings, graphite molds

Estimated payback time in years

Other factors such as TRU saved, safety

and reduction in radiation: Not included

\section{Category score}

1.00

This category score was arrived at by the analysis that a one year or less payback time is $100 \%$, to 5 years being $0 \%$, on a straight line basis. Therefore the 0.18 years equals a category score of 1.0 or $100 \%$. The category weighted score is $100 \%$ times the category weight of 0.55 or 0.55 .

Weighted Category Score (fraction of 0.55 ) 


\section{Total Score:}

As Shown in Figure 3 , the category scores reflect the individual fractions of a maximum score of 1.0 (e.g. C/B $0.55+$ Technical e $0.15+$ Resources e $0.15+$ Management e $0.15=1.0)$. For this task, the respectives summaries are: $0.55+0.15+0.15+0.113=$ 0.963 .

Figure 3 .
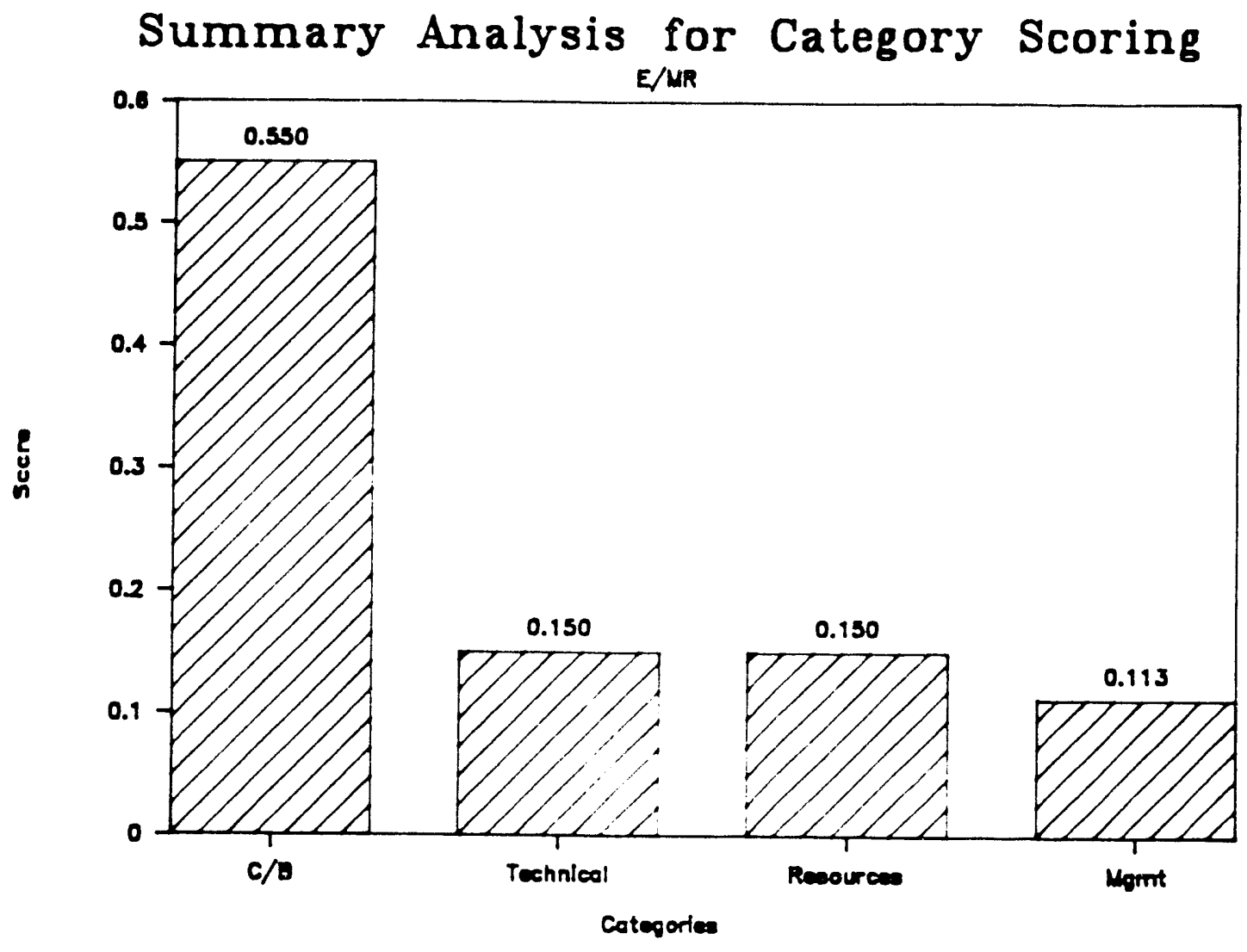
Guidance :

Work for FY87 will focus on examining other production hardware components for rare earth coating to, specifically, 1) replace the currently used $\mathrm{Mg}$ oxide crucibles with a rare earth composite coating on a steel crucible, and 2) continue coating technology with studies of other applications. Work elements are 1 ) develop and test a substrate layer for the new steel crucibles, $12 / 86,2$ ) design and fabricate test crucibles, 2/87, 3) refine the coating system, 4/87, 4) transfer technology on coating systems to production, $8 / 87$, and 5 ) complete summary report for fiscal year's activities, $9 / 87$.

Quality Level: B

Schedule/Milestones:

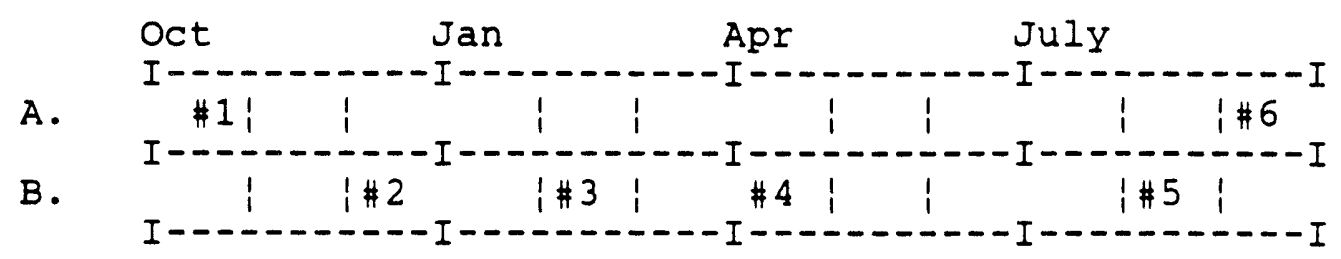

Reporting Functions:

1) Prepare a work plan of activities, $10 / 86$

6) Complete annual summary report, $9 / 87$

Work Functions:

2) Develop substrate coating, 12/86

3) Fabricate test crucibles, 2/87

4) Complete coating system refinements, 4/87

5) Complete technology transfer, $8 / 87$

Budget :

Funding requirements for FY87 are currently $\$ 130 \mathrm{~K}$. 


\author{
3.1 RWG - TRUEX \\ RL / RHO \\ Program Manager: \\ R. D. Wojtasek \\ Principal Engineer: \\ C. Manry, 440-3754 \\ N. Kirch, 440-2380
}

Objective

This task is for the technology transfer and implementation of the TRUEX process into the Hanford facilities. The generic process utilizes solvent extraction in conjunction with newly developed centrifugal contactors to selectively remove actinides from liquid waste streams. Development work on the process has been ongoing at ANL for the past several years, and thus far, on a laboratory scale, has shown to be applicable for removing actinides from process waste streams. Objectives of implementing the process at RHO will be to demonstrate the TRUEX process for recovering transuranics that would normally be lost to the waste stream and to terminate the transfer of transuranic waste streams to underground holding tanks.

\title{
Background
}

The development of the TRUEX process for recovery of TRU elements from acidic waste at the Plutonium Finishing Plant (PFP) is in progress. Other candidate waste streams for the TRUEX process are 1) stored alkaline waste liquors containing organic complexants (complexed concentrates), and 2) sludge resulting from neutralization of PUREX process acid waste. The TRU sludge resulting from neutralization of PFP acid waste prior to implementation of the TRUEX process at PFP is also a candidate. Acidification of complexed concentrate and acid dissolution of the PFP and PUREX plant sludges would be necessary to provide suitable feeds to the TRUEX process. Processing of these wastes could possibly be performed in an upgraded exisiting facility (B Plant).

The waste stream at the PFP has a volume of approximately 400,000 gal/year or 1,514,000 litres/year. The stream contains about $4.0 \times 10-3 \mathrm{~g} / 1$; therefore, about $6 \mathrm{~kg}$ is lost to the waste stream per year.

In FY86 a series of batch contact studies were performed to verify the TRUEX solvent extraction flowsheet using actual PFP waste. A bank of four laboratory-scale centrifugal contactors were fabricated at ANL and operated to gain familiarity with the equipment. Work tasks included purification of the CMPO compound, measurement of solvent quality, performing extraction tests, and verifying flowsheets. In additional work, solids from two effluent streams were collected and analyzed for radioactivity, particle size distribution, concentration of solids, and chemical composition. 


\section{Category Scoring}

Level of Development:

The level of development is between bench and pilot, giving a weighted score of $50 \%$ of the category weight of 0.15 or 0.075 .

Resource Requirements:

The resources for current task needs are in place, but not for implementation. A shortfall of $\$ 7.6$ million currently exists.

Current Budget Status

FY

Chemical Processing

TRU Lead Site

High-Level Lead Site

Totals
1987

$$
\begin{array}{r}
300 \\
800 \\
1,200
\end{array}
$$

2,300

Budget Needs

$$
3,600
$$$$
3,600
$$

1988

500

500

0

0

Budget Deficiency
1,300
3,100
1,600
1,600

1. Manpower: $1 \mathrm{MY}$

2. Equipment:

Scanning Electron Microscope Upgrade $60 \mathrm{~K}$ Particle counting System $45 \mathrm{~K}$

3. Work Area/Gloveboxes: Available for FY87

4. Facilities: Available for FY87

It appears that the money for implementation is not available. Therefore the category weighted score is $0 \times 0.15=\underline{0} . \underline{00}$.

\section{Management Involvement:}

Weight Factor: 0.15

Acceptance of management/operations and DOE? Yes; however, the funding does not reflect a total committment; therefore, only $50 \%$ is reflected to this score. 
Logical plan for task completion? A completion plan requires a more through breakdown than is currently available; therefore, only 508 is given to this item.

Final analysis shows $50 \%$ of the 0.15 weighted category, or a value of $\underline{0.075}$.

\section{Cost/Benefit Analysis:}

Information on the cost/benefit analysis was derived from the presentation materials "Application of TRUEX Process to Hanfurd." The cost of implementation is estimated at $\$ 10$ million. The number of canisters saved per year is 430 and at a treatment and disposal cost of $\$ 651,160$ per canister, the operational cost savings is $\$ 280 \mathrm{million}$. Therefore the payback time is $\$ 10$ $\mathrm{million} / 280 \mathrm{million} / \mathrm{year}=0.04$ years and yields weighted category score of $1008 \times 0.55$ or 0.55 .

Weight: 0.55

Task Cost:

Research and Development $\$ 130,000$

Pilot Plant

Implementation

$\$ 10,000,000$

Facilities

Sub Total Task Cost

$\$ 10,130,000$

Operational Costs:

Labor

Materials

Packaging

Certifying

Storage

Shipping

Disposal

Sub Total Operational Costs

$\$ 651,160$

Potential reduction in volume in $\mathrm{M}^{3} /$ year 430 canisters

Operational cost savings times the volumes of waste reduced $\$ 280,000,000$

Estimated payback time in years 0.04 years 
Other factors such as TRU saved, safety

and reduction in radiation: $20 \mathrm{~kg}$ of $\mathrm{Pu}$ could potentially be recovered using the TRUEX process.

Category Score

1.0

The weighted score was arrived at by the analysis that a one year or less payback time is $100 \%$, as compared to 5 years or more

being $0 \%$; therefore the $C .01$ years equals a weighted score of 1.0 $\mathrm{x} .55=\underline{0.55}$.

Weighted Category Score (Fraction of 0.55 )

\section{Total Score:}

As shown in Figure 4 , the category scores reflect the individual fractions of a maximum score of 1.0 (e.g. C/B e 0.55 + Technical e $0.15+$ Resources e $0.15+$ Management e $0.15=1.0$ ). For this task, the respectives summaries are: $0.55+0.075+0.00+0.075$ $=0.700$.

Figure 4.

\section{Summary Analysis for Category Scoring} TRUEX

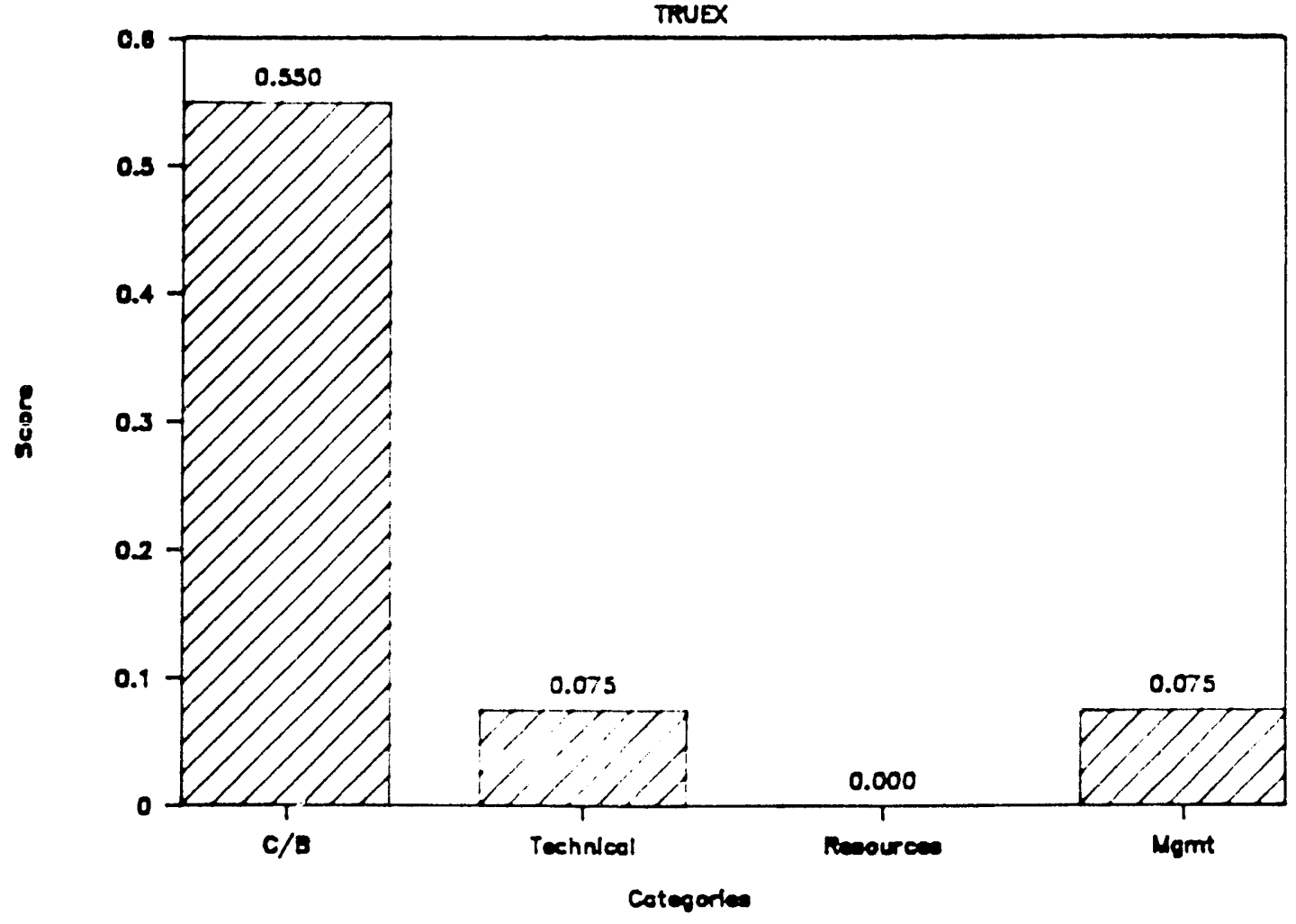




\section{Work Planned for FY87:}

Work for FY87 will focus on 1) optimization of the TRUEX flowsheet for the PFP, 2) determine disposal processing for americium, 8/87, 3) finalize a selection process for removing solids, $8 / 87$, and 4 ) initiate implementation of protoptype equipment for full-scale testing.

Quality Level: B

Schedule/Milestones:

A.

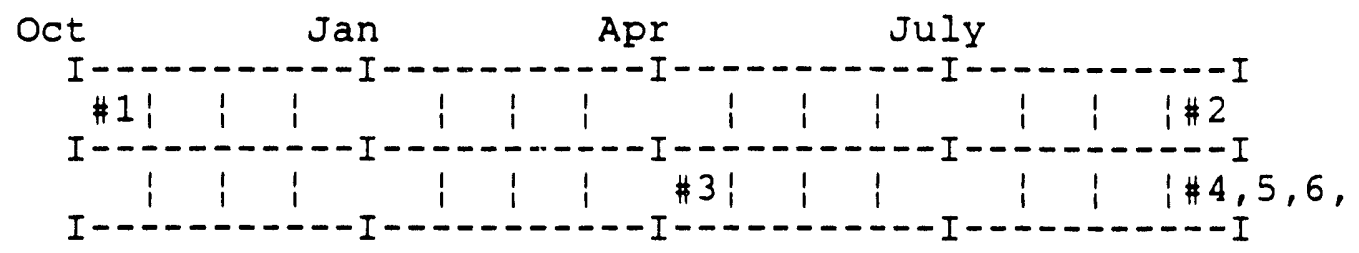

Reporting Functions:

1. Prepare a Current Year Work Plan for FY87, 10/86

2. Provide a Year End Summary Report, 9/87

Work Functions:

3. Finalize a selection process for removing solids, 5/87

4. Optimize the TRUEX flowsheet for the PFP, $9 / 87$

5. Determine disposal processing for americium, $9 / 87$

6. Initiate an implementation plan for protoptype equipment for full-scale testing, 9/87

Budget :

The FY87 budget for this task is $\$ 800 \mathrm{~K}$. 

Program Manager
Principal Engineer
C. Cargo
FTS 5831212
G. Becker
FTS
583-6182

\section{Objective}

The Process Experimental Pilot Plant (PREPP) is a facility to demonstrate methods for processing non-certifiable TRU waste into a form that is acceptable for WIPP disposal. During this processing wastes will be shredded, incinerated, sized for particle size by passing through a rotating trommel screen, and then the fines will be immobilized with cement. The task is to determine if the waste exiting the sizing step that are not classified as fines (greater than $1 / 4$ inches in diameter) can be segregated from the TRU category into the LIW category using non destructive assay technology.

\section{Background}

Studies in FY86 proposed instrumentation modifications/additions for sorting the waste. One technique utilizes neutron detection concepts and the other is based on gamma ray detection. The neutron detection technique is conceived as a variation of the TRU bulk waste assay instrumentation currently in use in the SWEPP and, therefore, considerable information is already available as to its workability. The system utilizes He-3 proportional counters in an appropriately designed collimator/moderator assembly.

The gamma ray detection systems depends upon the $60 \mathrm{Kev}$ photons due to $A m-241$. The intent is to detect the Am-241 photon and infer the quantity of TRU activity based on known correlation between the Am and TRU radionuclides.

Presently, it appeirs the neutron detection techn que is most appropriate to the application. Activities have focused on the design and testing of a prototype neutron detection system which will be an integral component of the PREPP process.

\section{Category scoring}

Level of Development:

The level of development $f c:$ this task is bench (2). The category score is then 0.50 or $50 \%$. The category weighted score is $50 \%$ times the category weight of 0.15 or $\underline{0.075}$.

Resource Requirements:

The resources for current task needs are in place, but not for implementation and consequently this needs to be resolved.

1. Manpower: $0.3 \mathrm{MY}$; $100 \%$ available 
2. Equipment:

Contractor will use existirg equipment or will try to borrow equipment from LANL

3. Work Area/Gloveboxes: PREPP; 1008 available

4. Facilities: Existing; $100 \%$ available

The weight factor for Resources is 0.15 . Because of the the uncertainties in implementation funding, only 0.5 or $50 \%$ is applied times the 0.15 factor. Therefore, the weighted category score equals 0.075 .

Management Involvement:

Weight Factor: 0.15

Acceptance of management/operations and DOE? Yes

Logical plan for task completion? Yes

$0.15 \times 0 \%=\underline{0.15}$ category weighted score

Cost/Benefit Analysis:

Weight: 0.55

Task Cost:

Research and Development $\$ 350,000$

Pilot Plant

Implementation (equipment)

$\$ 150,000$

Facilities

Total Task Cost

$\$ 500,000$

Operational Costs:

Labor

Materials

Packaging

Certifying

Storage

Shipping

Disposal

sub Total Operational costs

$\$ 5,000$

Potential reduction in volume in $\mathrm{M}^{3} /$ year

$71 \mathrm{~m}^{3}$ 
Operational cost savings times the volume of waste reduced

$\$ 355,000$

Estimated payback time in years

1.41 years

Other factors such as TRU saved, safety

and reduction in radiation: Not included

The payback time was found by dividing the total task cost by the operational cost savings. The category score was arrived at by the analysis that a one year or less payback time is $100 \%$, and to five years or more is $0 \%$ on a straight line basis; e.g. 1' $[$ Payback Time $-1 /(5-1)]=q \times x^{-55}$. Therefore, the 1.41 years equals a category score of $89.7 \%$. The category weighted score is 89.78 times the category weight of 0.55 or 0.494 .

Total Score:

As shown in Figure 5, the category scores reflect the individual fractions of a maximum score of 1.0 (e.g. C/B e $0.55+$ Technical e $0.15+$ Resources e $0.15+$ Management e $0.15=1.0$ ). For this task, the respectives summaries are: $0.494+0.075+0.075+0.15$ $=0.85$.

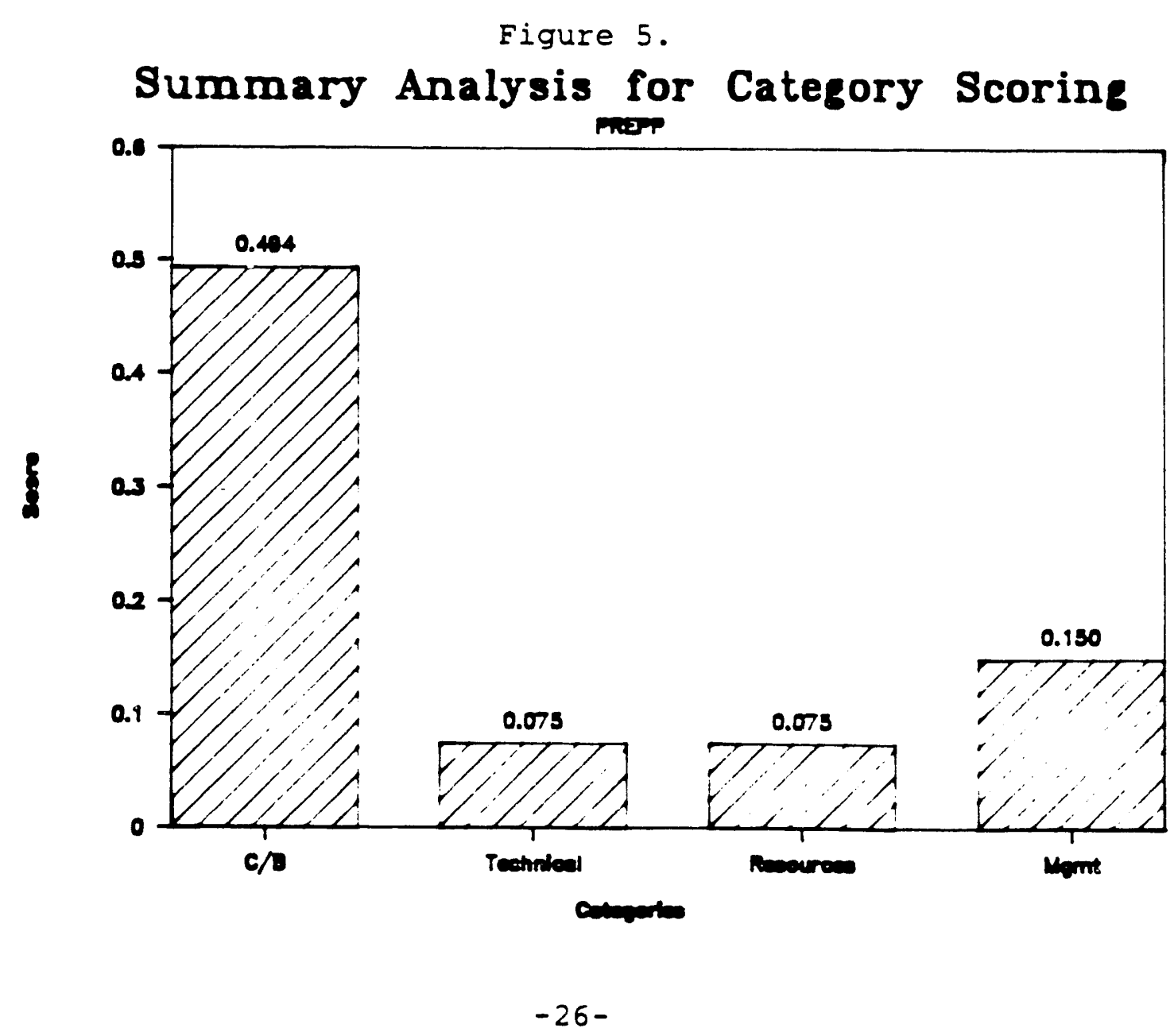


Elements of work in FY87 are to design a system capable of performing the identified task. This includes computer modeling of the instrument to provide input to the construction of the mockup. The mockup will be used to verify the model and to provide background experience in the construction of the actual instrument. A summary of all testing, acquired data, and mockup system performance will be in the year end final report. This report will contain sufficient information to assemble the instrument during FY88.

Quality Level: $B$

Schedule/Milestones:

A.

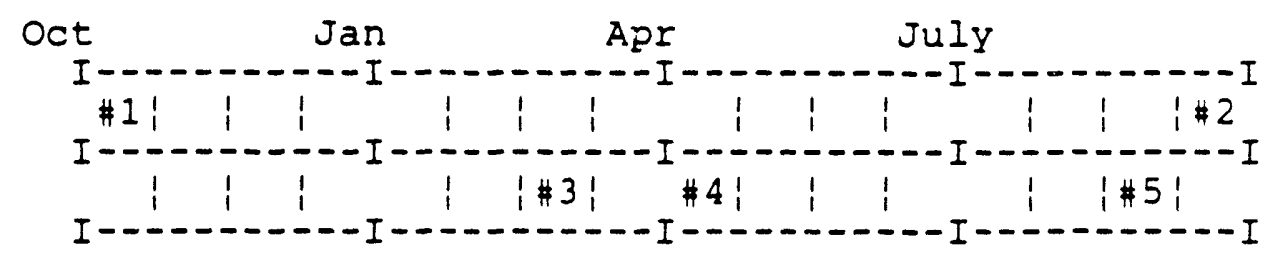

Reporting Functions:

1. Prepare a Current Year Work Plan, 10/86

2. Provide a year end report giving the results of the various analyses, and the evaluation of experimental data, $9 / 87$

Work Functions:

3. Design experimentation test plan, instrument mockup, data

acquisition/analysis, $3 / 87$

4. Identify test equipment and required materials, computer/mockup

intercomparison study, $4 / 87$

5. Perform tests and analyze data, $8 / 87$

Budget:

Funding is $\$ 50 \mathrm{~K}$ in FY87. 
Program Manager:

Principal Investigator:
J. J. Blakeslee

P. M. Arnold
$320-4642$

$320-2056$

\section{Objective}

The objective of the task is to improve methods of waste immobilization so as to reduce the overall waste volumes. The primary focus for improved immobilization will be aimed at the sludges generated at the Rocky Flats plant. Currently, 400-500 cubic meters of sludge is generated per year which is about 15 of the total volumes of TRU waste. Through improved immobilization practices, it is probable that a volume reduction in the range of $5: 1$ could be achieved.

\section{Background}

An economic analysis has been done comparing four types of solidification systems that could be implemented at the RFP Waste Processing Facility: I) microwave sintering, 2) GE AZTECH polyester solidification,

3) polyethtylene solidifiation, and 4) cementation. Results of this analysis show that the microwave sintering is the most cost effective, i.e. lowers the weight to be shipped by approximately one-half, and yeilds a cost savings of $\$ 750,000$ per year.

\section{Category Scoring}

Level of Development:

The level of development is at the bench (2) stage or 50\%. The category weighted score is then $50 \%$ of the category weight of 0.15 , or equals a factor of $\underline{0.075}$.

Resource Requirements:

The resources for the current research are available, but further work in out years is uncertain because of the nature of the task.

1. Manpower: $1.0 \mathrm{MY}$

2. Equipment: None

3. Work Area/Gloveboxes: N/A

4. Facilities: N/A

The weight factor for Resources is 0.15 , and it appears that the money for initial investigative purposes is available. Beyond this time the work is uncertain. Therefore $50 \% \times 0.15=0.075$ for a weight factor. 
Management Involvement:

Weight Factor: 0.15

Acceptance of management/operations and DOE? Supported by R\&D but uncertain about operations or DOE. Consequently $25 \%$ is allocated to the task.

Logical plan for task completion? No (0\%)

$258 \times 0.15=0.038$ category weighted score

Cost/Benefit Analysis:

weight: 0.55

Task Cost:

Research and Development

$\$ 130,000$

Pilot Plant

$\$ 1,700,000$

Implementation

Facilities

Total Task Cost

$\$ 1,830,000$

Operational Costs:
Labor
Materials
Packaging
Certifying
Storage
Shipping
Disposal

This analysis suggests that no additional processing costs will be involved, only that 200 cubic meters will not be shipped.

Sub Total Operational Costs

Potential reduction in volume in $\mathrm{M}^{3} /$ year

Operational cost savings times the volumes of waste reduced

Estimated payback time in years

Other factors such as TRU saved, safety

and reduction in radiation: Not included
$\$ 3,500$

200

$\$ 700,000$

2.61 years 
The payback time was found by dividing the total task cost by the operational cost savings. The category score was arrived at by the analysis that a one year or less payback time is $100 \%$ and to five years or more is $0 z$ on a straight line basis. The payback time of 2.61 years equals a category score of 0.596 or $59.6 \%$. The category weighted score is $59.6 \%$ times the category weight of 0.55 , or 0.328 .

\section{Task Total:}

As shown in Figure 6 , the category scores reflect the individual fractions of a maximum score of 1.0 (e.g. C/B e 0.55 + Technical e $0.15+$ Resources $0.15+$ Management $0.15=1.0)$. For this task, the respectives summaries are: $0.328+0.0 .75+0.075+$ $0.075=0.553$.

Figure 6.

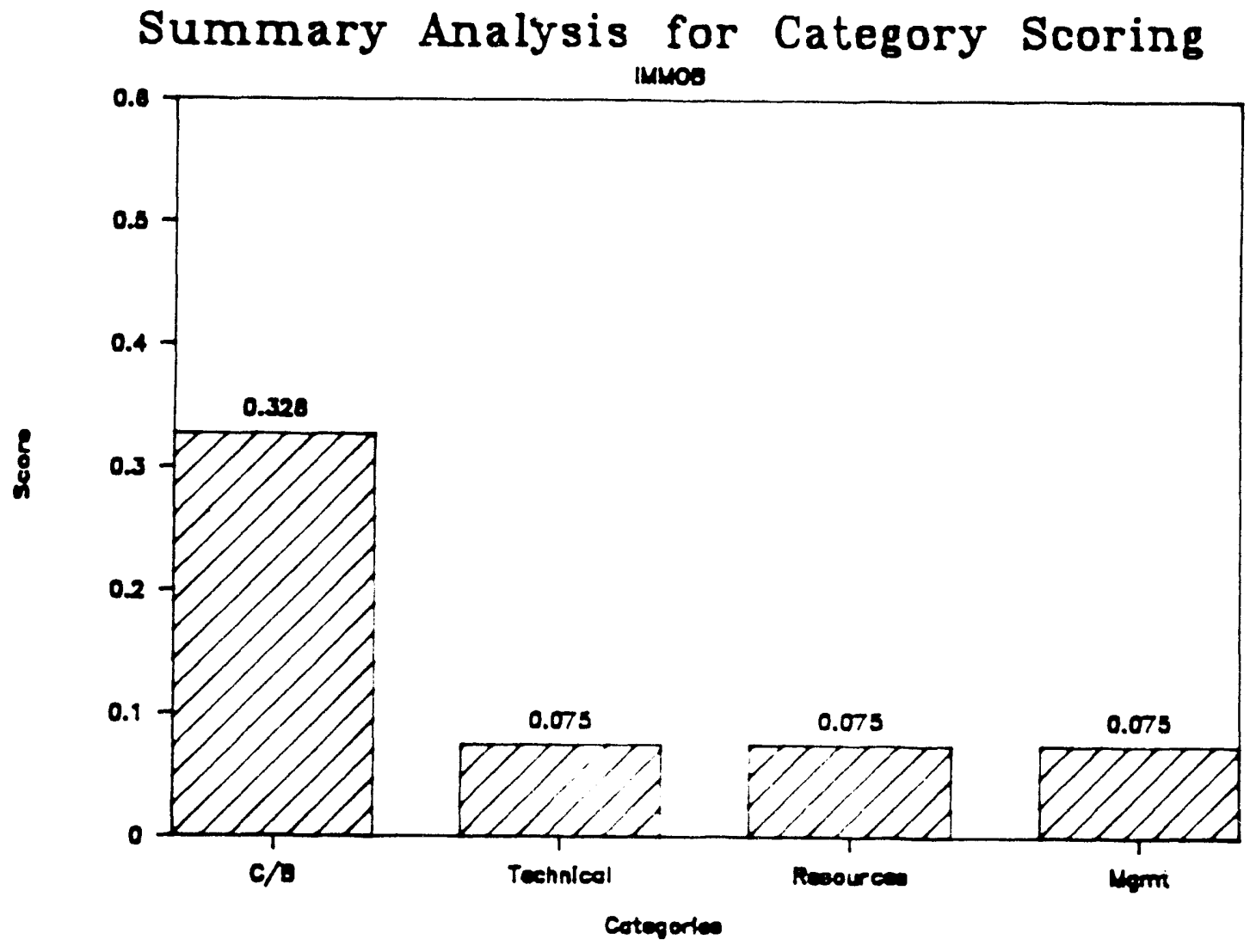


Guidance :

Work elements for FY87 are 1) a work plan will be devloped to evaluate technologies for immobilizing sludge wastes without the conventional cement and water, $10 / 86 ; 2)$ identify processes applicable for dry or wet sludge immobilization such as plasma furnace, microwave dryer-melter, induction melter, glass furnace and isostatic press, $6 / 87 ; 3)$ provide a survey of DOE defense sites where the technology would be applicable, and an inventory of the wastes which might be immobilized; 4) provide a cost/benefit analysis to measure the value of improved immobilization over cementation of TRU wastes, $8 / 87 ; 5$ ) prepare a year end summary report.

Quality Level: C

Schedule/Milestones:

FY87

A.

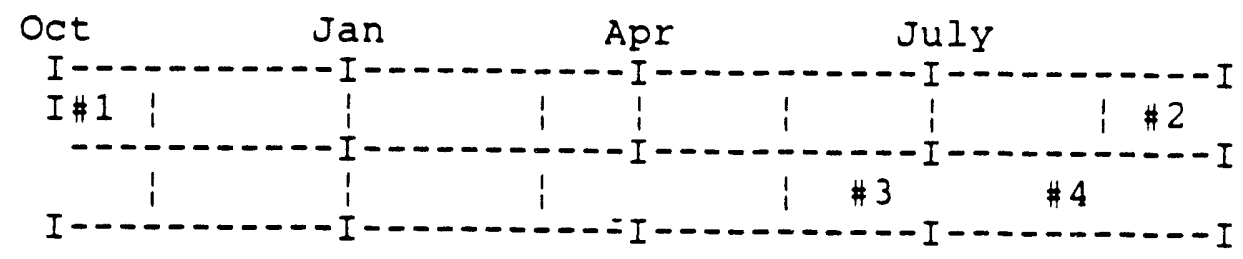

Reporting Functions:

A. 1. Current Year Work Plan 10/86

2. Complete FY 1987 SummarY Report

B. 3. Complete site visits and technology survey $6 / 87$

4. Complete Cost Benefit Analysis $8 / 87$

Budget :

Funding for FY87 is $\$ 130 \mathrm{~K}$. 


\subsection{RWG - ASSAY/SORT AT SOURCE}

Program Manager:

Principal Engineer:
AL/LANL

$100 \mathrm{~K}$

M. Lucas, $843-3116$

D. Close, 843-3683

\section{Objective}

The task is to develop a real-time go/no go counting system for segregating low-level waste from TRU waste at the source of generation.

\section{Background:}

Operational history at LANL, ORNL, RFP, Hanford, NTS, SRP, and INEL has shown that, by assaying waste containers using NDA systems, LLW can be effectively segregated from TRU, thus providing a cost savings in overall waste disposal. In furthering this concept, it is envisioned that additional segregation can be realized by sorting the waste in "up stream" processing areas where the waste is originally generated. Therefore, the task will be to determine the feasibility and necessary deviopment of an "assay/sort" NDA system at the source of generation. Factors to be considered are 1) can the equipment be emplaced without affecting current operations, 2) what are the shielding and other design requirements, and 3) if emplaced, what will be the projected volumes of wastes going to LLW instead of TRU, and what is the anticipated cost/benefit.

\section{Category Scoring}

Level of Development:

The level of development is at the theoretical or feasibility stage. The category score is then 0.25 or $25 \%$. The category weighted score is then $25 \%$ times the category weight of 0.15 or $\underline{0.038}$.

Resource Requirements:

1. Manpower: 0.75 MY 1008 available

2. Equipment: None, because this year's work focuses on the feasibility, $100 \%$

3. Work Area/Gloveboxes: LANL TA-18 laboratory, $100 \%$

4. Facilities: LANL TA-18 laboratory, $100 \%$

At this time, this task is considered to have all resources for completion available. The category score is then 100\%. The category weighted score is $100 \%$ times 0.15 or $\underline{0.15}$. 
Management Involvement:

Weight Factor: 0.15

Acceptance of management/operations and DOE? It appears at this stage of the investigation that the task does have management and DOE support; however, out-year activities will have to be evaluated before further funding.

Logical plan for task completion? The total plan for completion with all the available resources is not complete; therefore a $50 \%$ factor is given to this area.

Analysis: $0.50+0.25 \times 0.15=0.11$ category weighted score

Cost/Benefit Analysis:

At this time insufficient data is available for a routine cost/benefit analysis. Included in the work planned for FY88 will be to produce an estimated cost/benefit analysis.

Weight: 0.55

Task Cost:

Research and Development

$\$ 765,000$

Pilot plant

Implementation

$\$ 100,000$

Facilities

Total Task Cost

$\$ 865,000$

Operational Costs:

\section{Labor \\ Materials \\ Packaging \\ Certifying \\ Storage \\ Shipping \\ Disposal}

Sub Total Operational costs

Potential reduction in volume in $\mathrm{M}^{3} /$ year

Although there is insufficient information available for the cost benefit analysis, it is felt there is enough potential for savings to give this a weighted score of 0.55 . 
Operational cost savings times the volumes of waste reduced

Estimated payback time in years

Other factors such as TRU saved, safety and reduction in radiation:

Not included

Unweighted score

\section{Total Score:}

As Shown in Figure 7, the category scores reflect the individual fractions of a maximum score of 1.0 (e.g. C/B e 0.55 + Technical e $0.15+$ Resources e $0.15+$ Management e $0.15=1.0)$. For this task, the respectives summaries are: $0.55+0.038+0.15+0.113$ $=0.851$.

Figure 7.

\section{Summary Analysis for Category Scoring}

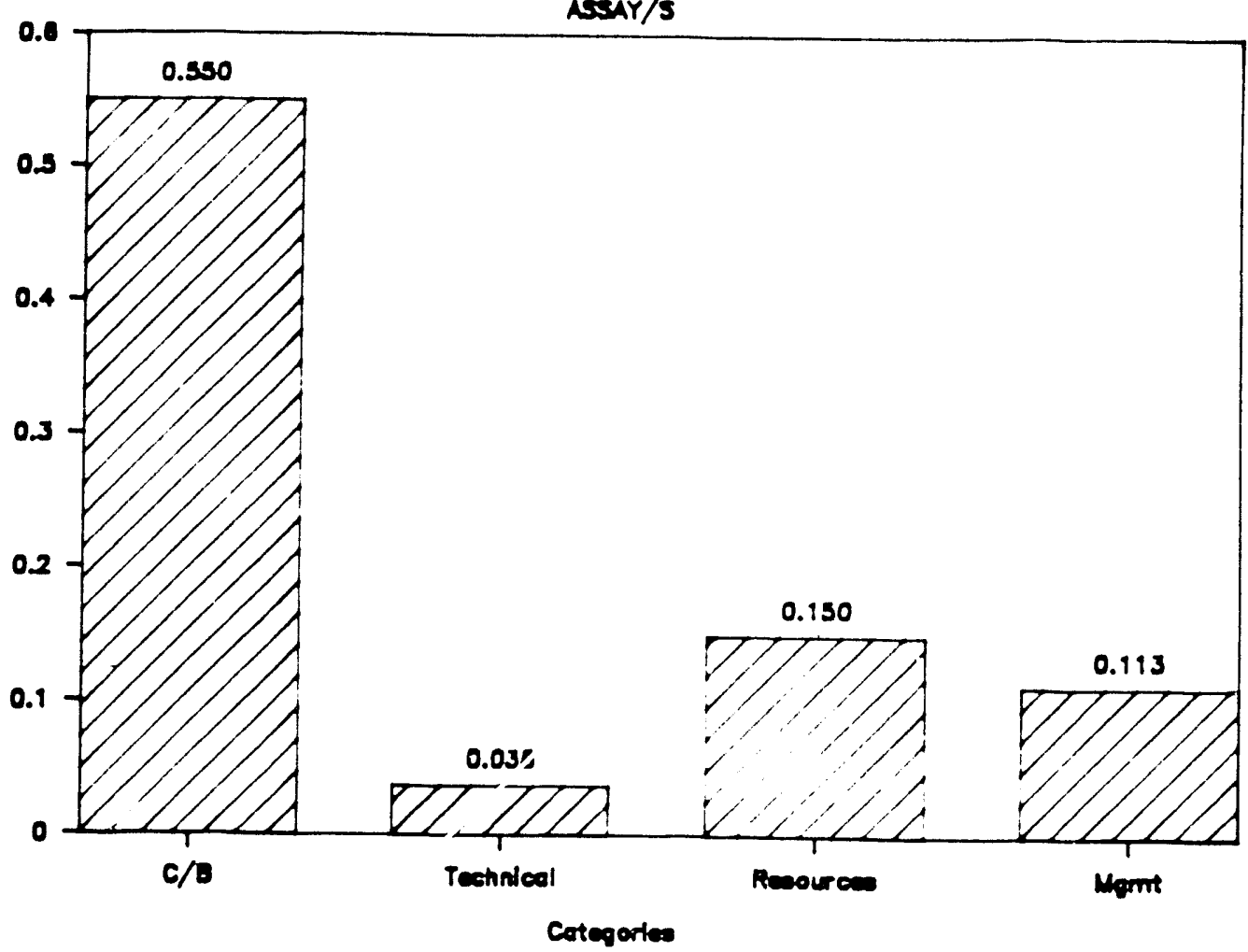


Guidance :

To initiate the task, studies will be made on site-specific assay/sort possibilities for gamma and neutron systems. A year end report will be prepared describing 1) the selection of a detector system that will give maximum sensitivity for gamma-ray and neutron detection at the less than $100 \mathrm{nCi} / \mathrm{gm}$ loading, 2) design of equipment for a waste handling system, and 3 ) experimental and calculational studies including recommendations for a specific real time go/no go sorting demonstration at a specific site.

Schedule/Milestones:

FY 87

A.

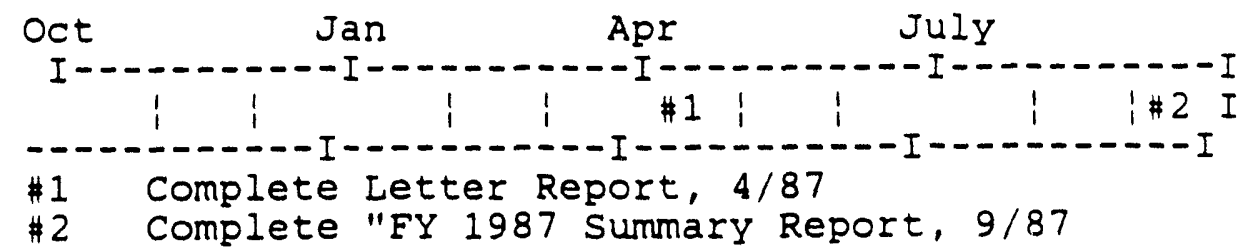

Budget:

Funding is $\$ 100 \mathrm{~K}$ in FY87. 


\section{Work Planned for FY88:}

\section{Guidance :}

In FY88 tests will be made using existing equipment at a selected site to demonstrate the "Proof of Principle." Elements of work will include procuring equipment, obtaining site concurrence for the demonstration, setting up the equipment, preparing a test plan, performing the test, and evaluating the results.

Schedule/Milestones:

FY88

A.

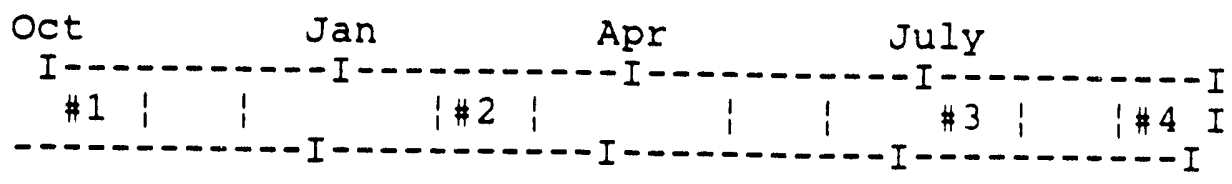

A.

\#1 Provide current year work plan, $9 / 87$

\#2 Provide experimental test plan for the demonstration, $2 / 88$

\#3 Complete test at selected site, $8 / 88$

\#4 Complete Year End Summary Report giving details of the experimental results with recommendations for site implementation, and a cost/benefit analysis of projected impacts resulting from implementation, 9/88

Budget :

Funding is projected to be $\$ 100 \mathrm{~K}$ in FY88. 


\section{Guidance :}

In FY89 the instrumentation design will be reviewed, finalized, and the instrument and associated equipment will be fabricated. The unit will then be tested for operability and reliability, and prepared for shipment to the selected site.

Schedule/Milestones:

FY89

A.

oct Jan

Apr JU1Y

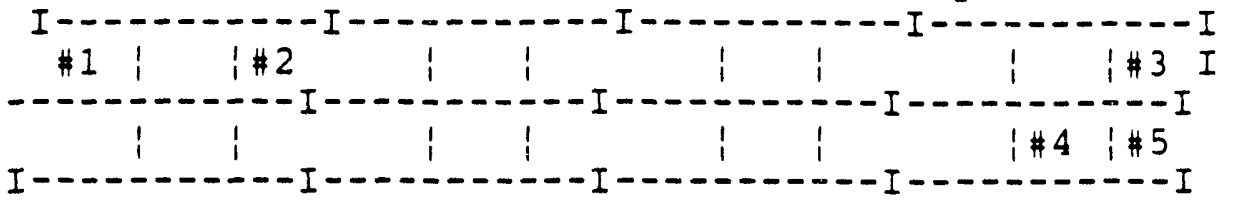

A. 1. Prepare a current year work plan, 9/88

2. Review selected design and make necessay changes, and complete design for construction of instrumentation package, $12 / 88$

3. Prepare a year end report giving result of laboratory tests and prepare an operational and spare parts manual, 9/89

B. 4. Construct instrument at $-T A-18,8 / 89$

5. Test unit and evaluate for operability in $T A-18$, and prepare for shipment to the selceted site for implementation, $9 / 89$

Budget:

Funding is projected to be $\$ 500 \mathrm{~K}$ FY89. 
Guidance :

FY90 will be the final year of the task, and elements to complete this work will include installing the NDA unit at a selected site, perform the operability tests, and krovide operator training to release the unit to the sits tor NDA sorting at the source.

Schedule/Milestones:

A.

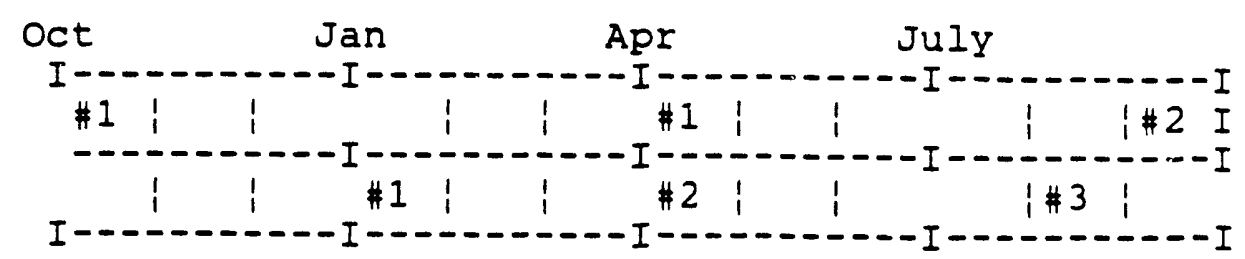

A. 1. Prepare a current year work plan, $9 / 89$

2. Complete Year End Report terminating project, 9/90

B. 1. Install constructed instrumentation at DOE selected site, $1 / 90$

2. Perform field test, evaluate and demonstrate workability,

3. Provide operator training and support to the facility which Budget: will include as built drawings and spare part list, 8/90

Funding is projected to be $\$ 250 \mathrm{~K}$ in FY90. 
OVERALL COMPARATIVE SCORING

OF FY87 TASKS

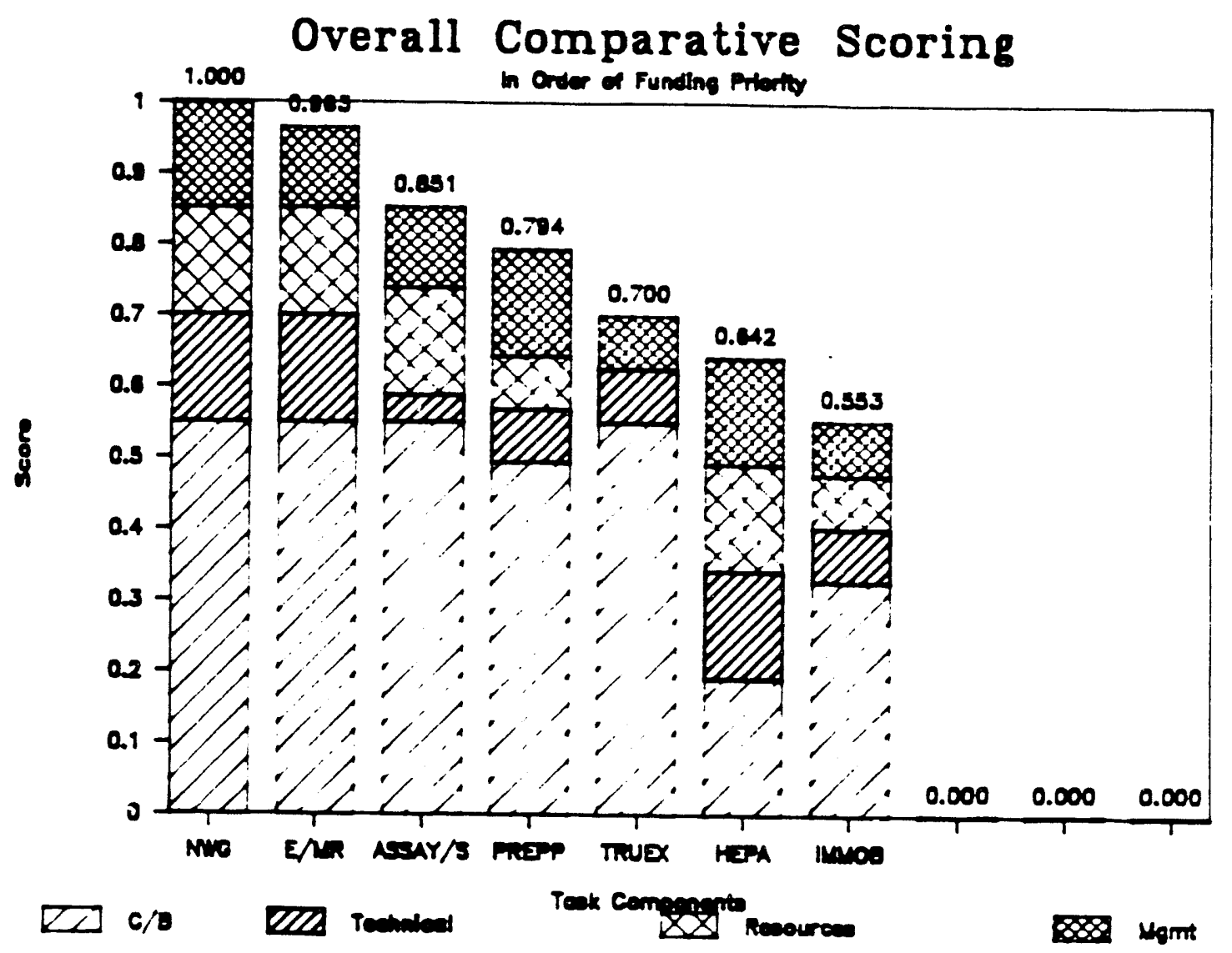


FY81

For information on past activities, the DTWP began funding tasks in FY 1981 at a level of $\$ 375 \mathrm{~K}$. The tasks and results for that year's funding are as follows:

1) Complete a site survey analysis for identifying major sources of TRU waste.

Reports were prepared entitled Current Trends in Transuranic Waste Generation at DOE Sites. These reports presented a profile of wastes being generated within the context of processes, categories, and waste volumes. In addition, since that time, and based on the same work, another document has been prepared entitled Characteristics of Transuranic Waste at Department of Energy Sites.

2) Complete studies for optimization and evaluation of basic electrolytes for electro-decontamination.

This work was brought to an understanding of validity for implementation, and then discontinued due to a change in funding priorities.

3) Determine the quantitative removal of actinides from process waste streams by using a new ferrite process.

Work confirmed the workability of the ferrite process on a laboratory scale: Actinides were removed from process waste solutions, and the solids were crystalline and magnetic, showing promise as a replacement for the existing carrier flocculant precipitation process. It was estimated that the ferrite process would eliminate $160 \mathrm{~m}^{3}$ of waste per year.

\section{$\underline{F Y 82}$}

In FY82, building on the previous year's tasks, at a funding level of $\$ 400 \mathrm{~K}$, the goals were to:

1) Continue the ferrite process development, including characterization of the waste solids and scale-up testing for plant operations.

Results for this task were optimization of the process for implementation into a production operation, discovery of a method to process liquids with interfering ions, and limited testing of the process with plant waste treatment equipment. 
2) Design a waste handing/storage system for USDOE sites.

The task resulted in the preparation of a waste charge system, which basically stated that the waste generators would pay for packaging, shipping, and storage. Revenues collected would either go to the storage site or DOE which would in turn fund the storage site for operations. After deliberation, the DOE decided that, although the charge system may provide an incentive to reduce waste, it would not justify the added cost of implementation and additional paperwork.

3) Identify and characterize oil and solvent waste streams for possible recycling or diversion from the TRU stream.

Reports were prepared identifying oil and solvent waste streams at RFP as potentially recyclable and diversionable. Studies were also initiated to determine the feasibility of recycling the oils and solvents.

FY83

For FY83 the funding level was again $\$ 400 \mathrm{~K}$, and the tasks and results were as follows:

1) Complete the design of the demonstration full-scale ferrite waste treatment plant, procure the needed equipment, and continue to support the projected production operation through laboratory work.

During FY83, demonstration runs were made on a plant scale that continued to show the workability of the ferrite process by lowering the actinide concentrations to levels below $10^{-8} \mathrm{~g} / \mathrm{l}$. Laboratory support work showed a diatomaceous earth pre-coat filter could be used for the final filter, eliminating the need for a previously required magnetic filter. This change in filters resulted in considerable cost savings in capital equipment. Additional work was performed on difficult-to-process waste streams and process optimization through methods of adding ferrite compound, and testing of a replacement for making ferrite by using magnetite. A seminar was held at RFP to provide the technology transfer of information on ferrite processing to other USDOE sites.

2) Implement a recycle process for a selected oil or solvent waste stream, demonstrate the recycle of additional waste streams, and isolate RFP non-TRU streams that were being treated as TRU waste.

Laboratory results for recycling oil and solvents showed a carry-over of Freon, trichlorethane, and other hydrocarbons that resulted in marginal acceptability of the product. The task for diverting non-TRU streams was implemented, which resulted in approximately 100,000 lbs of waste not
being classified as TRU. 
3) Prepare a handbook on Reduced Transuranic Waste Generation Technology.

The task was initiated with the gathering of information from USDOE sites on methods for waste minimization. Contents will include selection criteria, effectiveness, cost/benefit analysis, and ease of implementation.

\section{FY84}

For FY84 the funding level was $\$ 600 \mathrm{~K}$, and the tasks and results were as follows :

1) Implement a National Working Group for Reduction in waste Arisings.

This task was for the formation of a National Working Group for the Reduction in Transuranic Waste Arisings (NWGRTWA). Organizational objectives are 1) a means for information exchange between the different USDOE sites on ways in which the generation of TRU waste can be minimized, 2) a peer review of the progress and an evaluation of the tasks that are being funded under the DTWP, and 3) a catalyst for cooperative work tasks that can be undertaken between sites to achieve common objectives.

Task costs for FY84: $\$ 20 \mathrm{~K}$

The NWGRTWA held its first meeting in Northglenn, CO, October 14, 1983. Oganizational objectives were outlined and future tasks were defined.

The second meeting meeting was held at LANL, February 23, 1984, and the principal subjects of discussion were 1) clarification of operational definitions, 2) investigation of bagless posting systems, 3 ) review of proposed DTWP-RWA FY 1985 tasks, and 4) investigation of glovebox HEPA filters.

The third meeting of the National Working Group for Reduction in TRU Waste Arisings (NWGRTWA) was held at the Hanford House in Richland, Washington, July 19, 1984. The theme of this meeting was Reduction in waste Through Equipment Selection and Preventative Maintenance. In addition, presentations were made on proposed waste reduction design features for the new Special Isotope Separation (SIS) facility, status of the bagless posting systems being installed at SRP and LANL, systems study for remote handled waste, size reductiion using high pressure water cutting and the RHO/LANL arC saw, and an update of the FY85-86 proposed tasks for reduced waste generation. 
2) Completion of the "Handbook on Waste Minimization Techniques."

This task provided for the completion of a handbook on methods for reducing TRU waste volumes and transuranic content. The handbook identifies practical methods that can be implemented based on selection criteria, effectiveness, cost/benefit analysis, and ease of implementation.

Task costs for FY84: \$80K Total project cost (FY83 and FY84): \$116K

3) Completion of an analysis of sorting or techniques for removing waste from the TRU category.

This task provided for a cost/benefit study for in situ decontamination of $\mathrm{CH}$ and $\mathrm{RH}$ waste, including glove boxes and other large TRU contaminated components, into LLW. The impetus for this work was the redefinition of TRU waste based on the new DOE order 5820.2 .

Task Costs for FY84: \$60K.

A summary report was to be prepared by the end of the fiscal year that gives the results of this study. As was shown in the FY85 plans, the following year's technology transfer was made through presentations at the individual sites.

4) Completion of engineering studies to reduce waste.

This task provided for an analysis of engineering designs to effect a reduction in waste through studies of components and equipments in which changes effected their longevity. Within this analysis, studies were made of components and equipment that would last longer in harsh environments. Results of this study will be made available by the end of the fiscal year.

Task Costs for FY84: $\$ 40 \mathrm{~K}$

5) Provide for the implementation of the Ferrite Process.

This task was for the implementation of the ferrite process, which is a new method for removing actinides from process wastes streams. During the first week in July, the ferrite process was demonstrated on a plart scale for routine operation. Decontamination factors ranged from 100 to 1000 for a single stage process; therefore, this process shows adequate decontamination for subsequent solution processing for disposal.

A report is to be prepared by the end of the fiscal year describing the process in detail such as chemistry, operational data, cost/benefit, and other information necessary for technology transfer. 
Data was also obtained for converting the ferrite waste product into a form acceptable for disposal.

Total funding for this task in FY84 was $\$ 340 \mathrm{~K}$.

6) Design and testing of bagless posting systems.

This task provided for an analysis of methods in which waste could be removed from glove box lines using equipment such as bagless posting systems. The work included studies of bagout systems, not only within the US but within other countries, and the selection and cost/benefits that can be derived from such systems. Work included design and construction of a prototype system and testing in a demonstration mode. A report is to be prepared for distribution by the end of the fiscal year giving the results of these tests.

Cost for this work for FY84 totaled $\$ 60 \mathrm{~K}$.

\section{FY85}

For FY85 the funding level was $\$ 550 \mathrm{~K}$, and the tasks and results were as follows:

1) Continuation of the National Working Group for Reduction in TRU Waste Arisings

A US/UK Workshop on Reduction in waste Arisings was held at ORNL, MaY 13-15, 1985. A "FY 1985 Summary Report -- National Working Group for Reduction in TRU Waste Arisings" was prepared at the end of the fiscal year.

Task cost for FY85 was $\$ 40 \mathrm{~K}$.

2) Provide for technology transfer to USDOE sites on the use of in situ decontamination and other techniques for converting TRU waste into the LIW category. The basis of this work was the result of the previous year's task in which a cost/benefit study was performed to evaluate the utility of decontamination as a means for waste conversion.

Work included presentations to the major DOE sites on ways in which waste can be recategorized, and a summary report was prepared on the potential value of conversion principles to each site that included benefits, cost savings, and suggestions for improvement and/or implementation.

Task costs were $\$ 60 \mathrm{~K}$. 
3) Implement HEPA filter optimization and disposal technology.

The work included a systems analysis of HEPA filter handling techniques at the Rocky Flats Plant. An administrative change segregating first stage HEPA filters from secondary stage filters was implemented. This change reduced the amount of TRU filter waste by 50 percent. An analysis of the ways Low Level and TRU filters are processed indicated that a 60 percent reduction in LLW volume could be achieved by crushing the filters. Pre-filter selection was investigated and a recommendation to use a low pressure drop "furnace" filter was made to extend the service life of the first bank of HEPA filters.

Task cost for FY85 was $\$ 150 \mathrm{~K}$.

\section{4) Implement equipment/materials replacement.}

This task evaluated several production areas for equipment and materials replacement which would reduce the volume of metal waste being generated. In addition, an overall study was made of the metal waste category so as to provide a better insight into major sources and contributors to the metal waste inventory.

The results of the year's effort showed that most of the metal waste was from strip out operations and, therefore, little could be gained by equipment replacement. However, waste drums utilized to transfer waste on-site were identified as a signifiant source of metal waste. A procedural change for handing these drums at the size Reduction vault in Building 776 was developed and tested. The tests show that signifiant waste will be eliminated by incorporating the change into standard operating procedure.

Task costs for FY85 were $\$ 50 \mathrm{~K}$ expenses and $\$ 35 \mathrm{~K}$ capital.

5) Design and implement Bagless Posting.

This task was for the implementation and testing of a "Bagless posting System," which is a way of removing waste from process lines without the use of plastic and also provides for increased safety and a reduction in radiation exposure to workers. Implementation was based on the previous year's task which was to select the design and build a prototype system.

Results for FY85 were a detailed design description of a bagless posting system developed at the LANL. A report was prepared that includes brief descriptions of several related technologies, an account of the design considerations for a new system that evolved, objective and subjective test evaluations, and detailed drawings of the final prototype system. The report is intended to aid replication of the LANL prototype by others.

Task costs for FY85 were $\$ 150 \mathrm{~K}$. 


\section{6) Implement RWG technologies at Hanford.}

The task was for the implementation of reduction in waste generation technologies within two facilities at the Hanford site. One of the facilities is the Plutonium Finishing Plant (PFP), which is being upgraded for recommissioning, and the other is a special Isotope separation (SIS) facility currently in the conceptual design stage.

The activities to achieve the objective were 1) alternatives for waste volume reduction at SIS and PFP; 2 ) handling classified waste; 3 ) analyisis of gloveboxes; 4) use of high gradient magnetic filters in PFP; and 5) examine the use of Kynar-lined gloveboxes and windows.

1. For the task on alternatives for waste volume reduction, options examined such as compaction, melting, etc. proved economically feasible as opposed to no treatment. The option recommended for solid waste streams is incineration for combustibles and the recovery of Pu from the ash. The option recommended for liquid waste was liquid-liquid extraction (TRUEX) followed by ultrafiltration (HGMF).

2. Analysis of handing classified waste identified four alternatives. The most viable is to blend the classified waste with other waste when processed in the WRAP facility. A cost evaluation of push-through gloveboxes show lower total life-cycle cost for push-through gloveboxes, despite a higher initial purchasing cost.

Task costs for FY85 were $\$ 100 \mathrm{~K}$.

\section{FY86}

For FY86, the funding level was $\$ 510 \mathrm{~K}$ and the tasks and results were as follows:

1. Continuation of the National Working Group for Reduction in TRU Waste Arisings.

Two meetings were held this fiscal year: the first was a National working Group for Waste Reduction meeting, held at INEL, October 23-24, 1985 . Discussions focused on reduction in waste through 1 ) optimizing waste immobilization, 2) disposal of spent resins, 3) assay instrumentation for waste sorting at the source of generation, 4) reduction in pyrochemical waste salts through recycle, 5) laser cutting technologies, 6) PREPP volume reduction, and 7 ) super compactors.

The second National Working Group Meeting for Waste Reduction hosted the USDOE/ERG-BMFT Workshop on Waste Minimization and Processing at the Terrace Plaza Hotel in Augusta, GA, May 5 through 8, 1986. The workshop was held under the auspices of the Technical Exchange and Cooperative Arrangement Between the USDOE and FRG-BMFT in the field of management of radioactive wastes. 
Objectives of the workshop were to exchange information on methodologies for waste minimization during the sorting and processing of waste to meet disposal criteria. Several other related issues were also addressed such as safety and gas generation.

Task cost for the NWGRTWA for FY86 were $\$ 40 \mathrm{~K}$.

2. Continued HEPA life optimization work.

Work at RFP on HEPA filter optimization in FY86 focused on selecting and installing prefilters in plant HEPA filter plenums. The purpose was to determine if prefiltration systems could collect the larger particulates, and thus extend the lifetime of the first stage HEPA filters. Conclusions reached are that prefilters do perform the intended objective. When prefilters are fully implemented at RFP, the HEPA filters should last up to three times longer and provide a cost savings in the range of $\$ 400 \mathrm{~K}$ per year. In additional work, a prefilter remote handling system was designed which will allow the prefilters to be removed from the plenum system without physical entry into the plenums. Installation of the remote handling system, which is scheduled for FY87 as funds permit, will reduce radiation exposure to the filter change technicians and secondary waste resulting from entry and exit of the workers.

Task cost for HEPA life optimization for this fiscal year was $\$ 150 \mathrm{~K}$.

3. HEPA filter characterization.

Work at RFP on characterization of filters in FY86 determined if HEPA filters removed from the various plant air filtration systems, and as prepared for shipment through crushing, meet the WIPP Waste Acceptance Criteria for disposal. The results from this work show that the spent HEPA filters do not contain dispersible particulates in excess of the criteria and, therefore, the filters can be certified without immobilization processing. The estimated savings by avoiding this processing for HEPA filters is $\$ 1.6 \mathrm{million}$ per year.

Task cost for the characterization work this fiscal year was $\$ 100 \mathrm{~K}$.

4. Equipment materials replacement.

The work for equipment materials replacement focused on developing rare earth coatings for crucibles and other plutonium foundry hardware. Results of this work culminated in the development of a new composite coating system which is comprised of an external layer of erbium oxide over layers of chromium, calcium fluoride, and an internal layer of erbium oxide bonded to an oxidation-resistant steel alloy. When fully proven and accepted into production operations, the anticipated cost savings of this task by reducing the purchase of tantalum crucibles and disposing of graphite molds is in the range of $\$ 1$ million per year.

Task cost for this work in FY86 was $\$ 50 \mathrm{~K}$. 


\section{TRUEX}

Work in FY86 on the development of the TRUEX process proceeded in anticipation of the process being implemented in the Hanford Plutonium Finishing Plant in FY91. Primary efforts this year focused on studying the chemistry of the TRUEX process, testing the centrifigual contactors, and resolving questions concerning the solids in the waste stream.

In studies of the TRUEX compound, purification procedures were outlinea, and batch extractions were performed to verify extraction coefficients and the proposed flowsheet. Studies with the centrifugal contactor evaluated hydraulic performance, diluent loss by evaporation, and nitric acid extraction/stripping. For work on the solids in solution, various analysis were performed to determine total activity, particle size distribution, concentration of solids, and chemical composition.

Task cost for the TRUEX work in FY86 was $\$ 120 \mathrm{~K}$.

6. PREPP volume reduction.

Work at INEL in FY 1986 focused on determining the feasibility of sorting ILW from TRU waste within the PREPP facility and identifying NDA instrumentation for implementation. Conslusions drawn from this year's effort appear to be that a system can be devised to perform the waste segregation. Two NDA systems were identified, one utilizing neutron detection and the other gamma ray detection. The neutron detection system uses Helium-3 proportional counters in an appropriately designed collimator/moderator assembly. The gamma ray detection system depends on the $60 \mathrm{Kev}$ photons emmitting from Am-241. A correlation is then made to total TRU activity by assuming other proportional transuranic isotopic concentrations.

Task cost for this work in FY86 was $\$ 50 \mathrm{~K}$. 


\section{YEAR $\operatorname{COST}\left(000^{\prime} \mathrm{s}\right) \quad$ BENEFITS}

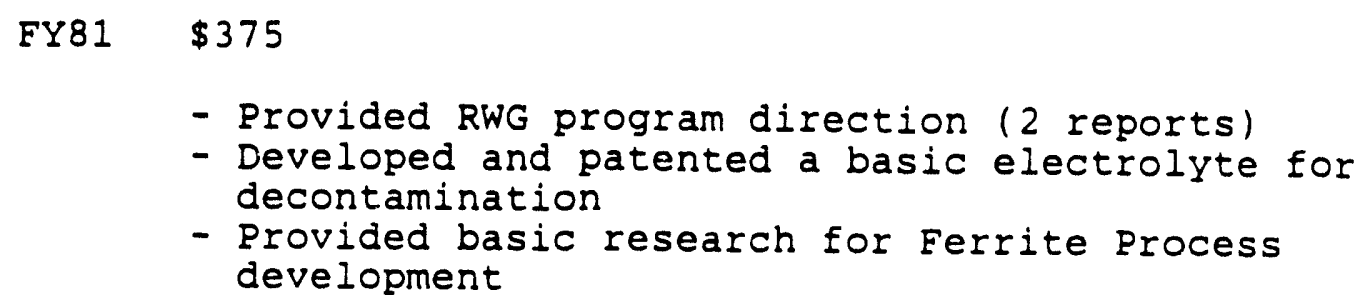

- Provided RWG program direction (2 reports)

- Developed and patented a basic electrolyte for decontamination

- Provided basic research for Ferrite process development

FY82 \$400

- Continued Ferrite Process development

- Designed standard waste charge system

- Initiated oil and solvent recycle

FY83 $\$ 400$

- Designed Ferrite Process for implementation

- Implemented procedure to eliminate oil and solvent streams from TRU waste * 100,000 lbs recatagorized into LLW

- Initiated RWG Handbook

FY84 \$600

- Implemented NWGRTWA

- Completed RWG Handbook

- Provided for an analysis of in situ decontamination and size reduction

- Provided for an analysis of equipment to extend life times

- Implemenţed the Ferrite Process for pilot testing $\star \sim 80 \mathrm{M} 3 / \mathrm{YR}$

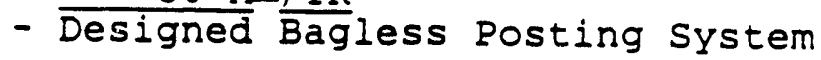


FY85 \$550

- Continued NWGRWA

- Provided technology transfer of in situ decontamination including potential benefits

- Implemented optimal HEPA filter use and disposal.

- Continued analysis of equipment for RWG $\star 25 \%$ of metal category reduced in volume at RFP

( $100 \mathrm{M}$ ) $/ \mathrm{YR}$

- Implemented Bagless Posting system for testing

- Implemented RWG technologies for SIS and PFP HGMS TRUEX

Kynar windows and glovebox liners

Push through windows

FY86 \$510

- Continued NWGRTWA

- Continued HEPA life optimization work

Cost savings estimated at $\$ 400 \mathrm{~K}$ per year

- Provided HEPA filter characterization

By avoiding processing of HEPA filters a cost saving is

anticipated in the range of $\$ 1.6$ million per year.

- Continued equipment/materials replacement work

Through the coatings work a cost savings of $\$ 1$ million per

year is anticipated

- Supported TRUEX work

- Continued support work on PREPP volume reduction 
DOCUMENTS PREPARED UNDER RWG TASKS

\subsection{ADMINISTRATIVE CONTROL}

Potential Methods to Reduce the Volume of TRU Wastes at Generation, Battelle, Columbus Laboratories, Columbus, Ohio, September 1981.

R. T. Jensen, Current Trends in Transuranic Waste Generation at Department of Energy Sites, CSE 81-0036, Rockwell International, Rocky flats plant, Golden, CO, October 1981.

R. T. Jensen, Alternatives for Reducing Transuranic Waste Generation, CSE 81-0043, Rockwell Intenational, Rocky Flats Plant, Golden Co., October 1981 .

R. T. Jensen, Evaluation and Proposal of a Waste Storage Charge System, Internal Report, CSE 82-0056, October 1982.

Transuranic Waste Management Systems Office Functional Area Plan for Reduced Waste Generation, Rockwell International, Rocky Flats Plant, February 1982 .

Transuranic Waste Management Systems office Functional Area Plan for Reduction in Waste Arisings FY 1984, TLO 84-1, Rockwell International, Rocky flats Plant, Golden, CO.

R. P. Allen and R. F. Hazelton, Conversion of Transuranic Waste to Low Level Waste by Decontamination - A Technical and Economic Evaluation, PNL-5315, Pacific Northwest Laboratnry, Richland, Washington, September 1984 .

In-Process Technigues for Reducing the Generation of Transuranic Waste, RFP-3737, Compiled and Edited by R. T. Jensen, Rockwell International, Rocky Flats Plant, Golden, Co, October 1984.

D. E. Bunnell and R. T. Jensen, HEPA Filter TKU Waste Generation Study, CSE85-083, Rockwell International, Rocky Flats Plant, Golden, Co, October 1985 .

R. D. Petersen, HEPA Filter Optimization, PSD86-060, Rockwell International, Rocky Flats Plant, Golden, CO, rctober 1986. 
G. F. Jaskot, HEPA Filter Waste form Evaluation, CSE84-054, Rockwell International, Rocky flats Plant, Golden, CO, November 1984.

R. G. Nieweg, Reduced Waste Generation Equipment Utilization, CSE85-071, Rockwell International, Rocky Flats Plant, Golden, Co., September 1985.

G. D. Poling, Equipment Selection and Testing Experience in Building 371 Plutonium Recovery Facility, CRD 84-070, Rockwell International, Rocky Flats Plant, Golden, CO, September 1984 .

A. G. Phillips and G. F. Spencer, Erbium oxide coatings for Plutonium Containment, PPC86-076, Rockwell' International, Rocky Flats Plant, Golden,

P. M. Arnold, Characterization of Spent HEPA Filters from Rocky flats Plant, PSD86-056, Rockwell International, Rocky Flats Plant, Golden, Co, September 1986.

\subsection{PROCESS DEVELOPMENT OR OPTIMIZATION}

T. E. Boyd and R. L. Kochen, Ferrite waste Treatment I: Preliminary Investigation, CRD 81-064, Rockwell International, Rocky Flats Plant, Golden, CO, October 1981.

T. E. Boyd and R. I. Kochen, Ferrite Waste Treatment II: Application to Decontamination and Decommissioning Waste Solution, CRD 81-089, Rockwell International, Rocky Flats Plant, Golden, CO, December 1981.

T. E. Boyd, R. I. Kochen, and M. Y. Price, Ferrite waste Treatment III: Application to /Waste Processing in Building 374, CRD82-001, Rockwell International, Rocky Flats Plant, Golden, CO. January 1982.

T. E. Boyd and R. L. Kochen, Ferrite waste Treatment IV: Continuous Processing of Rocky Flats Aqueous Process Waste, CRD 82-082, Rockwell International, Rocky Flats Plant, Golden, CO., August 1982 .

T. E. Bo:rd and R. L. Kochen, Ferrite waste Treatment V: Preliminary Immobilization Studies on Ferrite Solids, CRD 82-090, Rockwell International, Rocky Flats Plant, Golden, CO., October 1982.

T. E. Boyd, R. L. Kochen, and M. Y. Price Ferrite waste Treatment VI: Chemical Interferences in Actinide Removal by Ferrite Treatment, CRD 82-108, Rockwell International, Rocky Flats Plant, Golden, Co, December 1982 . 
T. E. Boyd and R. L. Kochen, Ferrite Treatment of Actinide Waste Solutions: Continuous Processing of Rocky flats Process Waste, RFP-3476, Rockwell International, Rocky Flats Plant, Golden, CO, March i983.

T. E. Boyd and R. L. Kochen, Ferrite waste Treatment VII: Multi-stage Continuous Processing, CRD 83-021, Rockwell International, Rocky flats Plant, Golden, CO, March 1983.

T. E. Boyd and M. Y. Price, Ferrite waste Treatment VIII: Ferrite Production by oxidation of Ferrous Hydroxide Slurries, CRD 83-073, Rockwell International, Rocky Flats Plant, Golden, CO, September 1983.

P. E. Bain and R. E. Fray, FY 1983 Status Report: Ferrite Process Implementation, CRD 83-074, Rockwell International, Rocky Flats Plant, Golden, CO, October 1983.

T. E. Boyd and R. L. Kochen, Ferrite Waste Treatment IX: Use of Commercial Ferrite for Actinide waste Treatment, CRD 83-087, Rockwell International, Rocky Flats Plant, Golden, CO, November 1983.

T. E. Boyd, R. L. Kochen, and M. Y. Price, Removal of Radioactive Materials from Waste Solutions via Magnetic Ferrites, Proceedings of the ANS Topical Meeting on the Treatment and Handling of Radioactive wastes, pp-391-394, Battelle Press, Columbus, Ohio, April 1982.

T. E. Boyd, R. I. Kochen, J. D. Navratil, and M. Y. Price Actinide Aqueous Waste Treatment Studies Using Ferrites, Radioactive Waste Management and the Nuclear fuel Cycle, Vol. 4(2), pp 195-209, July 1983.

S. V. Williams, Jr., T. E. Boyd, and R. L. Kochen, Ferrite Waste Treatment CRD 84-094, Rockwell International, Rocky Flats Plant, Golden, CO, August
1984.

S. V. Williams, Ferrite Waste Treatment: September 1984 Implementation Test Run, CRD 85-051, Rockwell International, Rocky Flats Plant, Golden,

G. F. Jaskot, Oil and Solvent Recycle Program Summary Report, CSE83-0041, Rockwell International, Rocky Flats Plant, Golden, CO, October 1983.

G. F. Jaskot, Lathe Coolant Recycle Program, CSE83-0021, Rockwell

International, Rocky Flats Plant, Golden, Co, September' 1983.

G. F. Jaskot, Oil and Solvent Recycle Program, CSE82-0023, Rockwell

International, Rocky Flats Plant, Golden, CO, April 1982. 
R. A. Koenig, Reduced Waste Generation - Equipment Utilization, Development of Bagless Posting System, Technical Support section, Los Alamos National Laboratory, Los Alamos, New Mexico, October 1985.

\section{MISCELLANEOUS DOCUMENTS}

Waste Generation Reduction Study - FY 1980, RHO-CD-1034, Rockwell International, Rockwell Hanford Operations, Richland, washington, September 1980 .

K. N. Kirchner, et.al, HEPA Filter Monitoring Program Final Report September 1985, I\&CSE 85-021, Rockwell International, North American space Operations, Golden, CO, September 1985.

J. F. Livingston, HEPA filter Immobilization, CSE 85-070, Rockwell International, Rocky Flats Plant, Golden, CO, September 1985. 

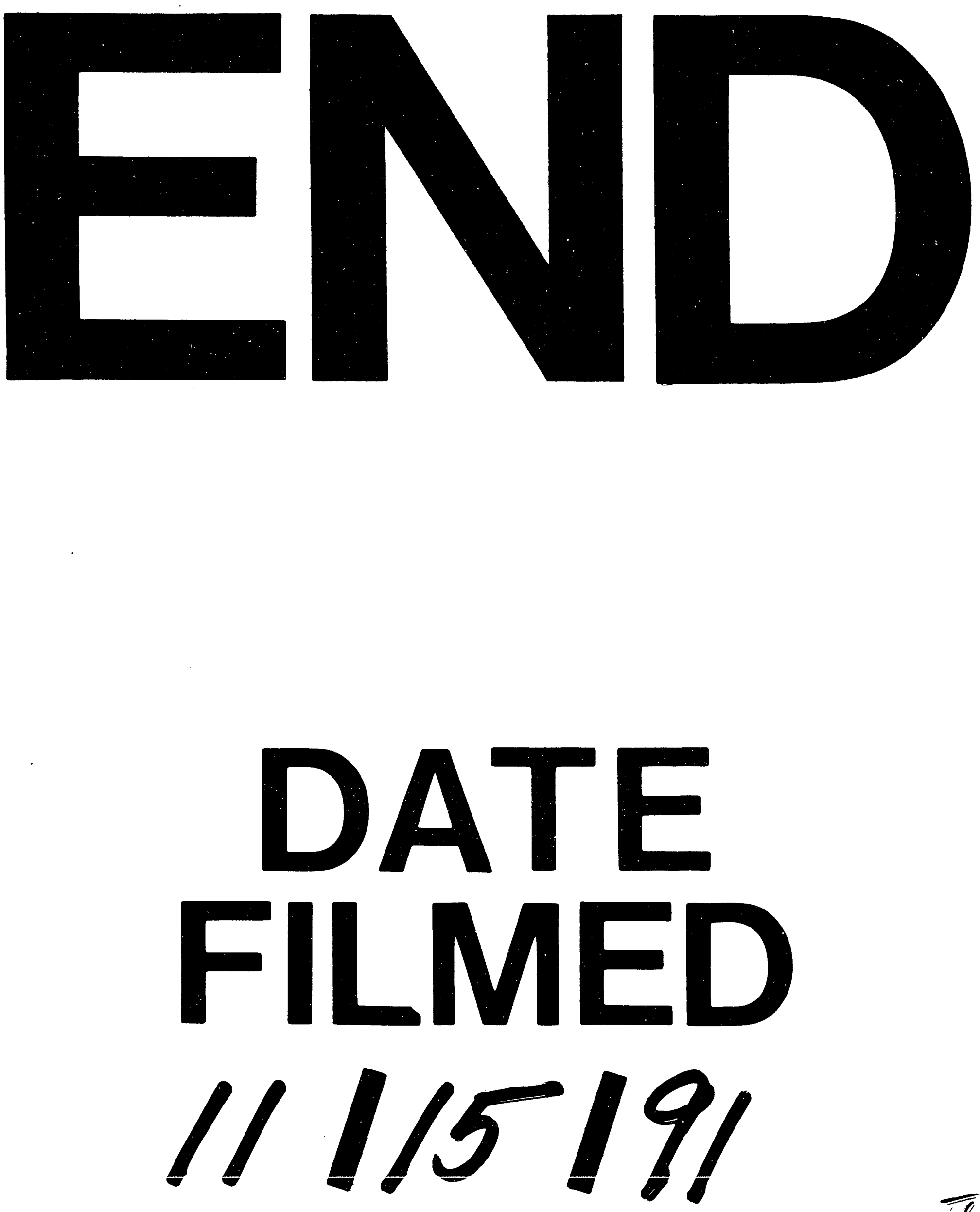
